\title{
Genomics: A Hallmark to Monitor Molecular and Biochemical Processes Leading Toward a Better Perceptive of Seed Aging and ex-situ Conservation
}

\author{
Zaheer Ahmed ${ }^{1}$, Zahid Hussain Shah ${ }^{2}$, Hafiz \\ Mamoon Rehman 3 , Khurram Shahzad ${ }^{4}$, \\ Ihsanullah Daur ${ }^{2}$, Abdalla Elfeel ${ }^{2}$, Mahmood ul \\ Hassan $^{5}$, Ali Khalid Elsafori ${ }^{2}$, Seung Hwan Yang ${ }^{6}$ \\ and Gyuhwa Chung ${ }^{6 *}$ \\ ${ }^{1}$ Department of Plant Breeding and Genetics, \\ University of Agriculture Faisalabad, Pakistan. \\ 2Department of arid land agriculture, King Abdulaziz \\ University Jeddah, Saudi Arabia. \\ ${ }^{3}$ Department of Electronics and Biomedical \\ Engineering, Chonnam National University, Yeosu, \\ Chonnam, Korea. \\ ${ }^{4}$ Department of Agricultural Sciences, Faculty of \\ Basic and Applied Sciences, University of Haripur, \\ Khyber Pakhtunkhwa, Pakistan. \\ ${ }^{5}$ Department of Plant Breeding and Genetics, Pir \\ Mehr Ali Shah Arid Agriculture University \\ Rawalpindi, Pakistan. \\ ${ }^{6}$ Department of Biotechnology, Chonnam National \\ University, Yeosu, Chonnam, Korea.
}

\section{*Correspondence: chung@chonnam.ac.kr}

DOI: http://dx.doi.org/10.21775/cimb.022.089

\footnotetext{
Abbreviations:

AFLP, amplified fragment length polymorphism

AGO, argonaute

miRNA, micro RNA

NGS, next generation sequencing

PCD, programmed cell death

PIMT, protein L-isoaspartyl methyltransferase

PRC2, Polycomb repressive complex 2

RAPD, random amplification of polymorphic DNA

ROS, reactive oxygen species

SSR, simple sequence repeat

TUNEL, terminal deoxynucleotide transferasemediated dUTP nick-end labeling

qRT-PCR, quantitative reverse transcriptional polymerase chain reaction
}

\begin{abstract}
For human food security, the preservation of 7.4 million ex-situ germplasm is a global priority. However, ex situ-conserved seeds are subject to aging, which reduces their viability and ultimately results in the loss of valuable genetic material over long periods. Recent progress in seed biology and genomics has revealed new opportunities to improve the long-term storage of ex-situ seed germplasm. This review summarizes the recent improvements in seed physiology and genomics, with the intention of developing genomic tools for evaluating seed aging. Several lines of seed biology research have shown promise in retrieving viability signal from various stages of seed germination. We conclude that seed aging is associated with mitochondrial alteration and programmed cell death, DNA and enzyme repair, anti-oxidative genes, telomere length, and epigenetic regulation. Clearly, opportunities exist for observing seed aging for developing genomic tools to increment the traditional germination test for effective conservation of ex-situ germplasm.
\end{abstract}

\section{Introduction}

Seeds can be defined as embryonic plants that are enclosed in protective outer coverings, seed coats, along with stored food that provides nutrients for post-germination seedling growth. Seeds have both biological and economic importance, because they are required for reproduction in many plant species and almost all crop species that are used as staple foods (e.g., maize, wheat, rice, barley, and beans) are reproduced through seed. Thus, seeds are agents of plant dispersal and important contributors to human food security.

Over the centuries, many of the useful plants that have been domesticated are no longer used for commercial agricultural production and are becoming increasingly rare, as a result of many factors. This phenomenon is resulting in the loss the genetic diversity, which is a prerequisite for improving existing plant genetic resources. In 
previous studies, Fu (2003), Fu and Somers (2009), and Nevo et al. (2012) used molecular biology and genomic techniques to demonstrate that both crop production and the food supply are vulnerable to genetic loss and that there is a need to increase the genetic diversity of various gene pools.

In many plant species, genetic diversity can be preserved for long periods through ex-situ conservation, in which seed is stored at a low temperature $\left(-20^{\circ} \mathrm{C}\right)$ and moisture content (Walters et al., 2005). However, not all seeds can be stored under these conditions, and based on their resistance to desiccation, seeds can be separated into two groups: (1) orthodox seeds, which can hold their germination potential over extensive intervals of dry storage, can sustain extreme desiccation by the end of their maturation, and are suitable for exsitu conservation; and (2) recalcitrant seeds, which cannot survive the desiccation involved in ex-situ conservation (Roberts, 1973). Presently, $\sim 7.4$ million compliances ex situ are preserved in over 1750 gene banks worldwide (Dulloo et al., 2010), and $90 \%$ of these genetic resources are preserved as seeds.

During ex-situ conservation, the physiological activities of seeds are interrupted but not fully arrested, and the conditions under which the seeds are stored (e.g., low temperature and humidity) affect the ability of the seeds to germinate, although this also depends on their initial quality (Schoen et al., 1998; Walters et al., 2005; Kaviani, 2010; Arif et al., 2012; Huang and Song, 2013), and contribute to seed deterioration and aging over long periods.

Seed aging, which has been described as the loss of seed quality overtime (Coolbear, 1995), reduces seed vigor and viability and threatens the abilities of researchers and growers to maintain reliable genetic resources and to conduct effective crop production, respectively, especially for crops harvested during the vegetative stage (Tekrony and Egli, 1991; Ateinzar et al., 2006). In a previous study, the germination of more than 14 ex situconserved germplasm collections were tested, and low germination was observed for many of the collections, particularly for wheat, rye, buckwheat, soybean, and onion. For example, the germination of the wheat germplasm was reduced from 92 to $65 \%$ within 16 years of ex-situ conservation (Weber et al., 2005). These observations suggest that ex situ-conserved seeds are subject to reduced viability over time and that it is necessary to constantly monitor seed aging in order to maintain viable seed stocks.

Currently, germination tests are used to evaluate the viability of ex situ-conserved seeds (Smith et al., 2003); however, the procedure is time-consuming and labor-intensive and fails to provide information about seed aging. Therefore, monitoring of seed aging needs speedy viability analysis, which should be innovative, low-cost, and equally reliable (Dona et al., 2013). Current progress in genomics and seed biology has unraveled new horizons for efficient handling and conservation of ex-situ seed germplasm under extensive storage period (Scheler et al., 2015). Therefore, genomic and biochemical markers could be used to monitor seed aging; however, comprehensive knowledge of the complicated network of molecular and biochemical processes that mitigate seed longevity is needed in order to select appropriate markers, which can then be used to gather useful information about the aging and viability of ex-situ seed stocks.

\section{Aim of this review}

Seed aging is a complex physiological trait that is controlled by a network of molecular and biochemical processes. At present, the basic strategy for monitoring seed aging is the accelerated, or artificial, aging test, which is also regularly used to investigate seed vigor. The molecular mechanism of seed viability and seed aging has largely remained unclear, until recently (Nonogaki et al., 2010). Therefore, traditional germination tests may be unable to diagnose the specific problems for seeds that are stored long term, and the development of some sensitive tools for monitoring seed aging has become critically important.

In recent years, our understanding of the molecular and biochemical processes involved in seed aging has progressed extensively, and discoveries regarding aging mechanisms, programmed cell death (PCD), and the role of mitochondria and epigenetics have improved our understanding of seed viability and deterioration. It has been identified by numerous inclusive reviews: reactive oxygen species, lipid peroxidation mediated by free radicals, imbalances in growth-regulating enzymes, enzyme activation or protein degradation, posttranslational modification of proteins, impairment of metabolic transition, damage to genetic integrity, and commotion of cellular membranes as main factors of seed aging (Priestly, 1986; Smith and 
Berjak, 1995; Walters, 1998; McDonald, 1999; Ventura et al., 2012; Rajjou et al., 2012; Table 1).

During the past two decades, extensive efforts have been made to understand the physiology of seed aging, but the genetic mechanisms underlying seed deterioration are yet to be identified (Nguyen et al., 2012). The aim of this review is to identify sensitive signals for seed aging from current development in seed cellular and molecular biology and genomics. Consequently, we can develop new genomic approaches for monitoring seed aging. We hope that our endeavor may bridge the gap between basic academic research and applied seed biotechnology so that ex-situ conservation can be used more effectively.

\section{Seed desiccation tolerance and suitability for ex-situ conservation}

Seeds, which develop from double-fertilized ovules, represent the main reproductive strategy of flowering plants (Rajjou et al., 2012). Following double fertilization, both the embryo and storage tissue begin to grow and continue to grow until a specific time, which depends on the particular plant species. When the development of the embryo is repressed on the mother plant and storage products are collected, by the aid of compound regulatory complexes that incorporate genetic programs, metabolic signals and pathways for hormonal signaling, seed maturation starts to acquire tolerance against desiccation (Ventura et al., 2012). However, not all seeds can withstand desiccation, and only orthodox seeds can be stored ex situ in their dehydrated state for long periods, which is regulated by complex networks of molecular and biochemical processes.

As opposed to recalcitrant seeds, the orthodox seeds activate various protective processes during maturation, and these processes can preserve DNA and the integrity of cellular membranes. These processes also facilitate the maintenance of desiccation tolerance (Smith et al., 1995; Berjak and Parmenter, 1997; Parmenter and Berjak 1999; Boubriak et al., 2000; Buitnik et al., 2002; Weitbrecht et al., 2011). When $90 \%$ of cellular water in a seed is removed and the seed maintains the

Table 1. Disruptive changes and their consequences on seed aging and deterioration.

\begin{tabular}{|c|c|c|c|}
\hline Disruptions & Associated Changes & Effects & References \\
\hline Membrane degradation & $\begin{array}{l}\text { Loss in membrane permeability and more } \\
\text { electrolyte leakage }\end{array}$ & $\begin{array}{l}\text { Decline in germination, vigour, as well } \\
\text { as seedling emergence. Diminishing of } \\
\text { cell function and energy production }\end{array}$ & $\begin{array}{l}\text { Walters et al., 2010; Guan et al., } \\
2014\end{array}$ \\
\hline Enzymes Alterations & $\begin{array}{l}\text { Reduction in the activities of ribonuclease, } \\
\text { lipase, protease, acid phosphatase, diastase } \\
\text { peroxidase, amylase, DNAase, catalase and } \\
\text { dehydrogenase enzymes. }\end{array}$ & $\begin{array}{l}\text { Increasing production of ROS and } \mathrm{H}_{2} \mathrm{O}_{2} \\
\text { and seeds become more receptive for the } \\
\text { oxidation of PUFA present in membrane. }\end{array}$ & $\begin{array}{l}\text { Biabani et al., 2011; Hancock et } \\
\text { al., 2015; Jin and Pie, } 2015\end{array}$ \\
\hline $\begin{array}{l}\text { Changes in Cell Chemical } \\
\text { Constituents }\end{array}$ & Decrease in total sugars, protein. & $\begin{array}{l}\text { Decrease in oligosaccharides associated } \\
\text { with membrane stability. }\end{array}$ & $\begin{array}{l}\text { Verma et al. (2003); Hussain et } \\
\text { al., } 2015\end{array}$ \\
\hline $\begin{array}{l}\text { Reduced Metabolic } \\
\text { Activity }\end{array}$ & Reduction in metabolic activities & $\begin{array}{l}\text { Fall in the ability to form nucleic acid } \\
\text { and nucleotides }\end{array}$ & $\begin{array}{l}\text { Astegar et al., 2011; Kumar et } \\
\text { al., } 2015\end{array}$ \\
\hline Free Radical Damage & $\begin{array}{l}\text { ROS oxidizes fatty acids in the absence of } \\
\text { enzymes. }\end{array}$ & $\begin{array}{l}\text { Damage the components of cell which } \\
\text { leads to deterioration of oil seeds }\end{array}$ & $\begin{array}{l}\text { Shelar et al., 2008; Li and He, } \\
2015\end{array}$ \\
\hline Chromosome Aberrations & $\begin{array}{l}\text { Damage in chromosomal structure leads to } \\
\text { expression alterations. }\end{array}$ & Promotion of seed ageing & $\begin{array}{l}\text { Ghassemi-Golezani et al., 2010; } \\
\text { Walters et al., 2010; Astegar et } \\
\text { al., } 2011\end{array}$ \\
\hline $\begin{array}{l}\text { Collapse of functional } \\
\text { structure }\end{array}$ & $\begin{array}{l}\text { Fall in ATPs level, decrease in sugar content, } \\
\text { failure of ribosome to dissociate, enzymatic } \\
\text { degradation, and starvation of meristmatic } \\
\text { cells. }\end{array}$ & $\begin{array}{l}\text { Increase in seed leachates and free fatty } \\
\text { acids contents that lead to seed aging } \\
\text { deterioration. }\end{array}$ & $\begin{array}{l}\text { Ghassemi-Golezani et al., 2010; } \\
\text { Santhy et al., } 2014\end{array}$ \\
\hline
\end{tabular}


capability to rehydrate effectively, it is considered desiccation tolerant. The molecular hydration shell is destroyed by reducing the moisture content of a seed to less than 23\% (Smith et al., 2003; Venturaet al., 2012; Sreenivasulu et al., 2013); however, numerous cellular processes subsidize to facilitate desiccation resistant seeds in the dehydrated state,e.g., presence of antioxidant systems; accretion of protective biomolecules, such as LEA (Late Embryogenesis Abundant) proteins, disaccharides (sucrose), and other oligosaccharides; activation of repair mechanisms during rehydration; and increase of amphipathic molecules (Osborne, 2000).

In contrast, the impairment of metabolic pathways and cellular membranes occurs as a result of cellular water loss during the dehydration of seeds that cannot endure desiccation. In the dehydrated state, the rates of membrane damage, protein denaturation, loss of enzyme functions, and nucleic acid integrity are influenced by the genetic makeup of the seeds, as well as the surrounding environment. Thus, seed moisture content is a core factor that modulates the balance of cellular functions and integrity (Osborne, 2000). In an experiment with Eugenia pleurantha, germination was significantly reduced when seeds were gradually dehydrated to 30,20 , and $10 \%$ moisture content, and germination was completely inhibited when the moisture content of the seeds was reduced to $7 \%$, with DNA seemed greatly degraded. However, in orthodox seeds, genetic stability was maintained at $7 \%$ seed moisture content. These observations support the hypothesis that, in orthodox seeds, the maintenance of DNA integrity during dehydration and DNA repair during rehydration are basic requirements for desiccation tolerance (Masetto et al., 2008). The DNA exhibits a specific conformation, but DNA enters different conformational states with the change in water content, and upon manifestation of dehydration, there is an increase in the number of base pairs per turn of the DNA helix. In response to water loss, the shift of DNA molecules to a more opposite conformation that can withstand dehydration is governed by various processes.

If chromatin or DNA conformation is not organized to facilitate dehydration, cellular damage can occur at the onset of dehydration. One important regulatory mechanism is the posttranslational modifications of histones, which ensures the appropriate chromatin structure (Ventura et al., 2012). In Arabidopsis thaliana, the HUB1 (Histone
Monoubiquitination) and HUB2 genes encode E3 ligases, which are necessary for the monoubiquitination of histone $\mathrm{H} 2 \mathrm{~B}$. It has been hypothesized that chromatin remodeling via monoubiquitination plays a basic role in the maintenance or induction of dormancy by regulating abscisic acid concentration and sensitivity in seeds (Liu et al., 2007). Another possible mechanism of chromatin remodeling is protein glycation, which is a non-enzymatic reaction between amino groups of proteins and reducing sugars. The transition of DNA is facilitated by histone glycation to a conformation well-suited with the desiccated state (Talasz et al., 2002).

When seeds are stored ex situ for long periods, the mechanisms that induce desiccation tolerance weaken with the passage of time. This reduced desiccation tolerance results in seed deterioration, which then results in seed aging and reduced viability. Viable seeds should imbibe on exposure to water and proceed to germination. A considerable outflow of cellular solutes occurs when water uptake begins, and this accelerates germination, by reducing the concentration of inhibitors, and is thought to damage cellular membranes, as a result of rapid or heterogeneous rehydration. Seed testa play an important role in regulating water intake rate (Koizumi et al., 2008). In late stages of germination and during imbibition, water is transported and distributed within the seed tissue by membrane proteins that facilitate the passage of small nonpolar molecules and water or aquaporins (Vijay et al., 2009).

In Arabidopsis, along with the upregulation of genes involved in transporting nucleotides to mitochondria by seed imbibition, a temporary upregulation of genes controlling mitochondrial DNA replication and translation is also observed. At the time of maturation, both membranes and mitochondrial enzymes are protected by LEA proteins (Tolleter et al., 2010; Law et al., 2012). Thus, a variety of cellular, molecular, and physiological processes contribute to seeds' ability to withstand desiccation and to resume germination under favorable conditions.

\section{Recent developments in the science of seed aging}

Owing to their importance in plant reproduction, extensive efforts have been made to understand the molecular, biochemical, physiological, and metabolic processes involved in controlling seed development and germination, and many published reviews 
describe the progress in the field of research (for detail see Bove et al., 2001; Chaudhury et al., 2001; Weber et al., 2005; Le et al., 2007; Linkies et al., 2010; Nonogaki et al., 2010; Rajjou et al., 2012; Ventura et al., 2012; Diaz-Vivancos et al., 2013; Sreenivasulu and Wobus, 2013).

Along with seed viability, seed vigor is another important parameter of seed quality. Seed vigor determines the strength and uniformity of the resulting seedlings. Recently, some PCR-based molecular markers, including RAPD, AFLP, and simple sequence repeat (SSR) marker shave been developed and are considered to be sensitive measures of seed vigor (Chwedorzewska et al., 2002; Vijay et al., 2009; Dona et al., 2013). However, in contrast to the rapid progress in understanding the molecular pathways and regulatory mechanisms involved in seed development, germination, and viability, the development of new technology for monitoring seed aging has progressed more slowly.

As a result, recent efforts have been increased, and the current understanding of the molecular and cellular processes related to seed aging has improved. For instance, the roles of reactive oxygen species (ROS) and anti-oxidative enzymes, PCD triggered by mitochondria and DNA alternation, molecular repairs (including DNA and protein), and epigenetic regulation are now beginning to be understood. Recently, it was reported that seed aging is related to cellular-level modifications, such as the loss of membrane integrity, RNA impairment, decreased energy metabolism and protein synthesis, and DNA degradation (McDonald, 1999; Corbineau et al., 2002; Kibinza et al., 2006; Ding et al., 2016); Osborne and Cheah (1978) and Osborne et al. (1981) reported the degradation of embryonic nuclear DNA during seed aging. However, DNA laddering commonly observed in active and genetically controlled PCD or unaddressed deprivation after intensive DNA oxidation may lead to DNA impairment (Stein and Hansen, 1999; Slupphaug et al., 2003).

\section{Cellular and physiological processes involved in seed aging}

\section{Mitochondrial alteration}

Germination is a complex and energy-demanding process that requires the proper operation of mitochondria, which must survive desiccation over long storage periods and become rapidly functional after imbibition to meet the ATP demand of various metabolic processes in germinating seeds. With the help of recent developments in the fields of molecular and cellular biology and molecular physiology, it is possible to validate the performance of mitochondria in aged seeds, up to a certain degree. During prolonged storage, mitochondrial dysfunction is supposed to be the main cause of seed aging. Meanwhile, in animal cells, mitochondrial alterations probably result in cell death (Bras et al., 2005) and are considered the main cause of agingin mammalian cells (Kujoth et al., 2005).

In the seeds of cereal crops, the biogenesis of mitochondria during germination is thought to proceed from the structural progression of alreadypresent mitochondria, whereas in lipid storing seeds, mitochondria are generated through de novo synthesis (Morohashi, 1986; Priestley, 1986; Shatters et al., 1995). Logan et al. (2001) proposed that, during imbibition, mitochondria from dry maize seeds depend on the oxidation of cytosolic NADH to differentiate into functional mitochondria. Meanwhile, the relationship between mitochondrial performance and germination was determined in pea (Pisum sativum L.) by analyzing the physiological properties of mitochondria isolated from normal, primed, and aged seeds (Benamar et al., 2003). The authors found that priming increased mitochondrial performance, whereas accelerated aging deteriorated pea seeds by strongly affecting the oxidative properties of mitochondria, thus impairing their ability to synthesize ATP. The results also highlighted that the integrity of the outer and inner mitochondrial membranes was the primary target for aged-induced damage and recovery.

Moreover, the monitoring of mitochondrial membrane stability during complete germination period reveals that the recovery and integrity of the inner mitochondrial membrane is more sensitive to desiccation than that of the outer mitochondrial membrane (Wang et al., 2012). The permeability of the outer mitochondrial membrane triggers caspasedependent apoptosis. However, the loss of its integrity results in the discharge of soluble proteins, like cytochrome $\mathrm{C}$, from intermembrane space (Lo et al., 2011). Till note, no staunch evidence is available to authenticate the role of mechanical factors in the deterioration of outer mitochondrial membrane integrity, and apoptotic mechanisms vary from organism to organism.

Overall, we can conclude that the segregation of mitochondrial DNA and division of mitochondria is 
facilitated by mitochondrial actin and that apoptosis or plant cell death is initiated by the dynamics of mitochondrial actin, which initiates the release of cytochrome C (Lo et al., 2011). These observations reflect the close association of mitochondrial membrane integrity and energy metabolism during aging. Thus, energy metabolism and seed deterioration are likely related, since the availability of energy determines seed viability and vigor. On the other hand, fluctuating moisture constituents have been reported to accelerate the impact of aging on the energy metabolism of artificially aged sunflower seeds (El-Maarouf-Bouteau et al., 2011), and the adenylate pool (ATP, ADP, and AMP) of these seeds was found to decrease markedly at higher levels of seed moisture level, as a result of mitochondrial dysfunction.

Mitochondrial alteration during early seed aging or germination is related to the recovery or damage ofthe inner and outer mitochondrial membranes. Recently, Wang et al. (2012) devised a strategy to quantify the recovery rate of the inner mitochondrial membrane after the imbibition of desiccationstressed pea seeds; they used an oxygen electrode system to calculate the mitochondrial consumption of oxygen and found that the recovery of mitochondrial function and structure followed a cumulative normal distribution. Along with the physiological changes mentioned earlier, on imbibition of dry seed many molecular changes like and increased expression of factors and genes regulating RNA processing and protein respectively, were also observed within mitochondria. Therefore, it can be deduced that these events are followed by an increase in the expression of genes that encode proteins responsible for the replication and translation of mitochondrial DNA. Moreover, the upregulation of genes for nucleotide synthesis in cytosol and nucleotide transportation into mitochondria has also been reported, and transcriptome analysis reveals a rise in transcript levels of genes that govern different metabolic and bio-energetic processes of mitochondria (Cao et al., 2015). Mass spectrometry and Western blot analysis of protein levels indicate a positive correlation between the proteome and transcription factors (Law et al., 2012).

\section{Programmed cell death (PCD)}

Lockshin and Zakeri (2004) described PCD as the sequence of (potentially interruptible) events that is associated with controlled cell death, and PCD can be generally described as apoptotic (type I) or autophagic (type II) cell death, in contrast to necrotic (type III) cell death, which is a non-physiological phenomenon induced by injury or infection. At the cellular level, PCD has been accepted as a primary process and is involved in development, defense, and stress responses (Reape and McCabe, 2008). Initially, the observation of cereal seed germination and aleurone autolysis was used to elucidate the role of PCD in seed viability. Gibberellic acid and abscisic acid are strongly correlated with the regulation of seed viability and inhibition of PCD, respectively (Fath et al., 2000; Chmielowska et al., 2015). Moreover, it is also assumed that ROS initiate the fundamental processes of PCD; as ROS threshold levels areattained, the PCD signal transduction pathway is triggered (Kranner et al., 2010; El-Maarouf-Bouteau et al., 2015). However, the mechanism by which ROS-initiated PCD contributes to reduced seed viability and vigor during aging is mostly unknown (Hossain et al., 2015).

El-Maarouf-Bouteau et al. (2011) reported that PCD resulted in a $50 \%$ reduction in the viability of sunflower seeds that were subjected to accelerated aging under different relative humidity and temperature levels. Both RAPD and AFLP analyses indicate that genomic DNA deterioration is associated with seed aging (Chwedorzewska et al., 2002; Kranner et al. 2006; Vijay et al., 2009); RAPD is also a reliable technique for diagnosing DNA deterioration (Liu et al., 2005) and mutational events, including point mutation, rearrangement, deletion, insertion, and structural distortion in bacteria, animals, and plants (Atienzar and Jha, 2006; Vijay et al., 2009).

To further confirm the role of PCD in seed aging, ElMaarouf-Bouteau et al. (2011) used the terminal deoxynucleotide transferase-mediated dUTP nickend labeling (TUNEL) assay, coupled with propidium iodide (PI; marker for cell death) and 4,6diamidino-2-phenylindole (marker for living cells) staining. In situ observations (TUNEL and PI staining) can be used to study PCD within individuals, whereas DNA breakage and mitochondrial failure function at the population level. The TUNEL assay detects apoptotic cells, whereas PI staining reports the co-localized nuclei of dead cells. The bright green fluorescent spots, which\% moisture content for 7 days at $35^{\circ} \mathrm{C}$ were subjected to PCD. Till note, no TUNEL reaction is evidenced in normal seeds. However, PI staining of seeds undergoing aging under the same conditions has confirmed reduced cell viability in the embryonic axis; El-Maarouf-Bouteau et al., 2011 reported that 
a positive TUNEL assay indicated that the embryonic axes of sunflower seeds aged at $37^{\circ} \mathrm{C}$, and TUNEL in situ hybridization maybe the most effective strategy for identifying PCD associated with seed aging. However, this strategy is relatively complicated and includes many steps, including material fixation, paraffin embedding and sectioning, TUNEL in situ hybridization, and microscopic examination.

In woody plants like elm (Ulmus pumila L.) seeds, PCD initiates the process of aging $(\mathrm{Hu}$ et al., 2012), and when these seeds are subject to controlled deterioration treatment, the electrophoresis of DNA extracted from the seeds exhibits typical DNA laddering, which is recognized as an important characteristic of PCD and apoptotic cell death in plant and animal cells, respectively. Western blot analysis has indicated that mitochondria begin releasing cytochrome $\mathrm{C}$ into the cytosol during the second day of controlled deterioration treatment. However, cytochrome $C$ is absent in the cytosol by the fifth day. In addition, the activity of DEVDase and caspase-3 are significantly increased during controlled deterioration treatment. Thus, the whole cellular area of seeds follows PCD unanimously under aging conditions. Since the simultaneous occurrence of PCD causes seed death, this process cannot be labeled as a selective removal of dead cells, as reported for other developmental processes or in response to pathogens (Hengartner, 2000), and mitochondria are also observed during PCD alterations, which contributes to their malfunction, thus facilitating the occurrence of PCD. In plant and mammalian cells, the interruption of energy metabolism does not affect seed viability, which verifies that mitochondrial death occurs in the early phase of PCD (Atlante et al., 1996; Vacca et al., 2004).

\section{Reactive oxygen species (ROS) and signaling}

Chemically reactive oxygen species are widely considered key factors of seed aging under prolonged storage and are generated by the reduction of molecular oxygen $\left(\mathrm{O}_{2}\right)$ to hydrogen peroxide $\left(\mathrm{H}_{2} \mathrm{O}_{2}\right)$, hydroxyl radicals $(\mathrm{OH})$, singlet oxygen $\left({ }^{1} \mathrm{O}_{2}\right)$, and superoxide $\left(\mathrm{O}_{2}{ }^{-}\right)$. Oxidative processes and the formation of free radicals are induced during various metabolic processes or under different stresses, such as dehydration. During the storage of dry seed, non-enzymatic mechanisms, such as lipid peroxidation, are thought to be responsible for the accumulation of ROS, owing to the absence of free water, whereas enzymatic mechanisms are responsible for ROS production during imbibition. However, in seeds with dynamic metabolic activities, the mitochondrial respiratory chain is thought to be the main source of ROS generation (Bailly, 2004), and the deposition of ROS can also be accelerated by alterations in mitochondria (Wei and Lee, 2002; Cash et al., 2007; Li et al., 2015).

Previously, ROS production and lipid peroxidation have been reported to increase, along with moisture content, in response to artificial aging (Kibinza et al., 2006). Seeds possess higher concentrations of polyunsaturated fatty acids than other plant tissues (Mansfield and Briarty, 1992). Therefore, large amounts of ROS are formed and deposited as a result of the peroxidation of polyunsaturated fatty acids (Bailly, 2004). Reactive oxygen species contribute to seed aging by triggering protein oxidation, membrane perturbation, mitochondrial dysfunction, and genetic damage (Coolbear, 1995; Khan et al., 2015) and are believed to induce porosity in mitochondrial membranes, which then initiates apoptosis, owing to the discharge of cytochrome $\mathrm{C}$ and other apoptogenic components into the cytoplasm (Tatton and Olanow, 1999). The intensity of cellular damage caused by ROS depends on the ability of seeds to eliminate oxidative agents via enzymatic and non-enzymatic antioxidation systems. In fresh seeds, harvested from various rice genotypes, the total antioxidant potential is under direct genetic control; however, in aged seeds, environmental factors might play a role, as well (Talai and Sen-Mandi, 2010). The enzymatic anti-oxidative system comprises a number of enzymes, including ascorbate, catalase, superoxide dismutase, and glutathione reductase. These major antioxidant enzymes can scavenge excessive ROS from within plant tissues (Bailly, 2004) and use different mechanisms to remove ROS from the organelles or cells. During the germination of several plant species, superoxide dismutase activity plays a critical role in balancing ROS at non-toxic levels (Wojtyla et al., 2006). In tobacco (Nicotiana tabacum), overexpression of the superoxide dismutase gene alleviates seed deterioration during aging (Lee et al., 2010), and the expression of various anti-oxidative genes inpre- and postgerminative pea seeds has been elucidated in response to seed aging(Yao et al., 2012). Moreover, genes located in the cotyledon and embryo axes of germinating seeds are highly expressed, and in young seedlings, expression was detected in cotyledons, roots, and shoots. On the other hand, the rapid aging of pea seeds reduces seed viability and seedling growth. Deviation in transcriptional 
activation of eminent antioxidant genes indicates a positive correlation with this effect (Yao et al., 2012). Accelerated lipid peroxidation from oxidative stress reduces the activities of anti-oxidation enzymes that play important roles in seed aging.

In sunflower seeds, reductions in seed viability and vigor that occur during aging are associated with accumulation of hydrogen peroxide, accelerated lipid peroxidation, and reduced activity (Kibinza et al., 2006; Nagel et al., 2009; Li et al., 2015). Metallothioneins (MTs) serve as signaling molecules and ROS scavengers, both within and outside the nucleus,(Wang et al., 2010), which highlights their potential interaction with DNA repair machinery (Balestrazzi et al., 2011). Since signals monitoring seed aging can be classified into five categories: molecular, biochemical, physiological, metabolic, and mitochondrial (Fu et al., 2015), we have devised an integrated model that elucidates the pathways exhibiting positive and negative effects of these signals on seed aging and germination (Figure 1). These signals are highly complicated and interconnected; therefore, it is difficult to tag specific fingerprints of various aging stages. Balestrazzi et al. (2009) provided convincing evidence of the putative protective roles of MTs in the nucleus. The researchers demonstrated that the Pisum sativa PSMTA1 gene encodes an MT-like protein that eliminates the risk of oxidative DNA damage by conferring protection against oxidative stress. In Arabidopsis thaliana, seed-specific type-4 MT (MT4a and MT4b) mRNAs accumulates during late embryogenesis and rapidly vanish during imbibition, which highlights the possible role of MTs in desiccation tolerance (Kranner and Colville, 2010; Najdekrova et al., 2012). The carbonylation of proteins occurs in aged seeds following oxidative stress (Rajjou et al., 2008), which makes them susceptible to degradation, resulting in loss of activity. During imbibition, seed aging also induces the inhibition of the de novo synthesis of proteins, such as fructose-1,6-bisphosphate aldolase (FBPA), which is related to metabolic processes (Rajjou et al., 2008). In dry seed, water uptake is required to activate antioxidant enzymes and for germination to take place. However, this uptake reactivates various metabolic processes, thus contributing to the production and deposition of ROS, which may inhibit germination (Wituszynska et al., 2015). On the other hand, the production of ROS, such as $\mathrm{H}_{2} \mathrm{O}_{2}, \mathrm{O}_{2}{ }^{-}$, and hydroxyl $(\mathrm{OH})$ radicals, is directly associated with germination (Schopfer et al., 2001). Therefore, successful germination strongly depends on effective anti-oxidative processes that can maintain sufficiently low limits of ROS (De Gara et al., 1997; McDonald et al., 1999).

Although ROS are deleterious to cells and tissues, they regulate plant growth and development by loosening cell walls during cell elongation (Miller et al., 2008). In isolated segments of maize modulated ROS yields $\mathrm{H}_{2} \mathrm{O}_{2}$, which boosts leaf expansion (Rodriguez et al., 2002). Moreover, in germinating pea seeds high amount of $\mathrm{O}_{2}^{-}$deposits at radicle expansion stage (Kranner et al., 2010), which validates the role of $\mathrm{O}_{2}{ }^{-}$in stimulating cell elongation (Passardi et al., 2004; Barba-Espin et al., 2011). Apart from their deleterious effects, ROS play a pivotal role in the signal transduction system of seed. Therefore, seed germination probably only occurs when the level of ROS is sustained under a critical threshold (i.e., oxidative window for germination), which then triggers ROS-mediated signaling pathways (Figure 1). Recently, DiazVivancos et al. (2013) summarized new discoveries involving ROS and their interaction with growth regulating hormones in the regulation ofseed germination.

\section{Molecular processes involved in seed viability}

There are quite a few pathways that have been identified to play roles in seed germination, thanks to recent developments in genomics and molecular physiology (Rajjou et al., 2012), and some of them have been confirmed to be pivotal factors of seed viability.

\section{DNA repair}

Most DNA damage related to seed aging is a consequence of oxidative stress that occurs during desiccation and extensive periods of storage (Linkies et al., 2010). DNA damage results in single and double strand breaks, which subsequently results in reduced seed viability and seedling vigor; thus, DNA damage must be repaired during germination (Liu et al., 2005). Till note, little is known about the complicated repair mechanisms of DNA in plants. In plants, both nucleotide and base excision repair pathways are supposed to be the most prominent DNA repair processes. Various DNA ligases are involved in DNA repair. In the genomes of the nucleus, chloroplast, and mitochondria, replication, recombination, and repair processes are facilitated by multiple ligase genes. Investigation of the Arabidopsis genome has verified the occurrence of three DNA ligases, including two homologs (AtLIG and AtLIG4) of yeast/animal DNA ligases I and IV, respectively. However, a third ligase (AtLIG6) encodes protein domain specific to plant 


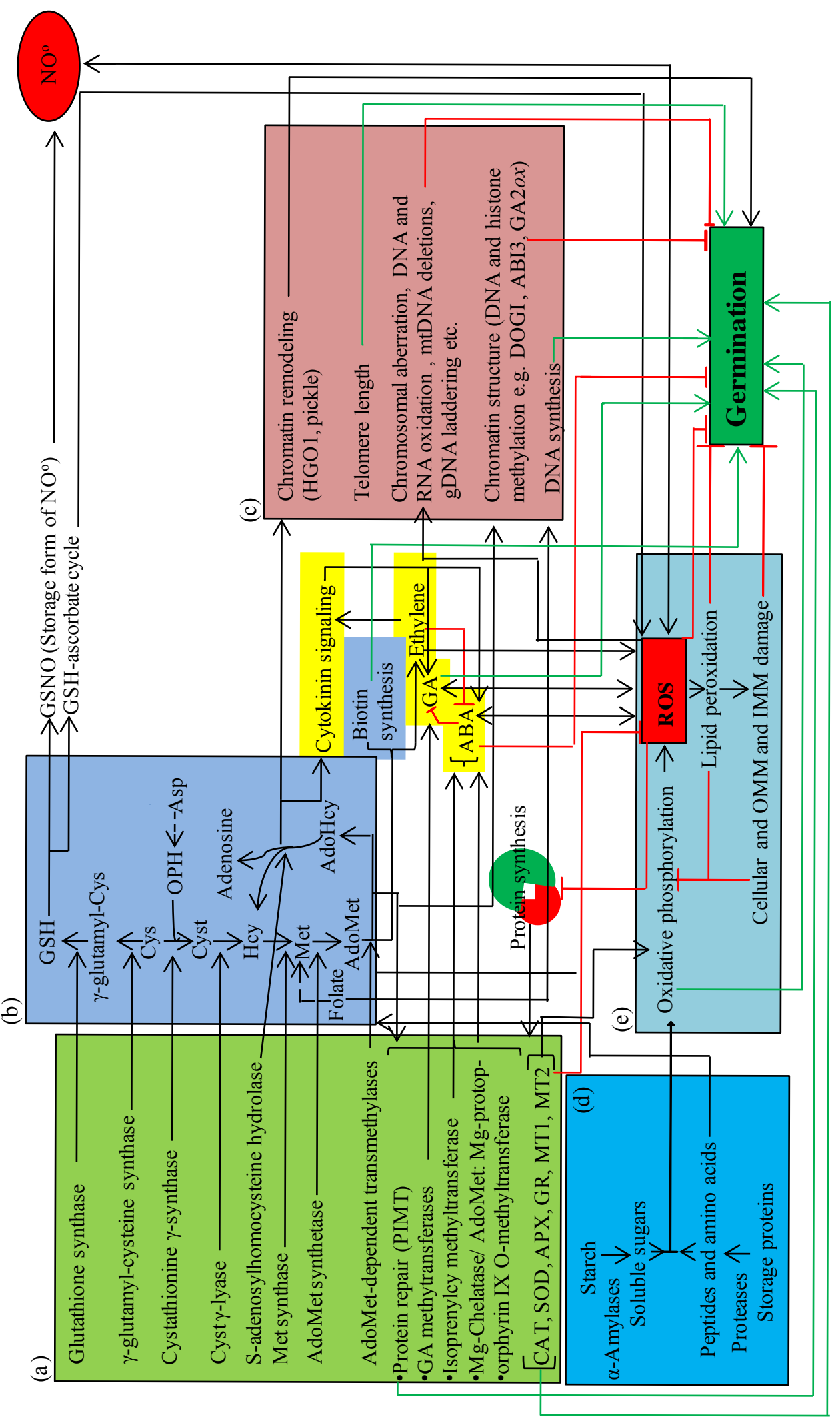

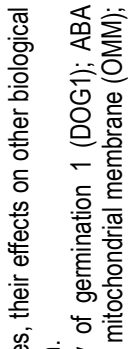

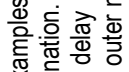

खे

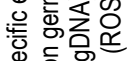

क⿺辶万

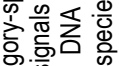

क्षे $\frac{0}{\pi} \cdot \frac{0}{0}$

등 응 잉

क 高离竞

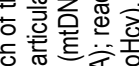

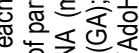

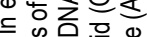

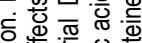

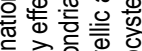

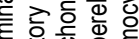

응응ㅇㅇㅇ 흥

列

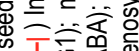

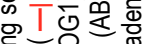

등 을 웅

足

흥

तु

으을

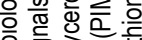

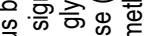

을 중중

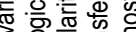

드응응 흉

政

娄

음

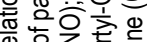

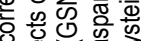

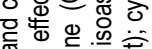

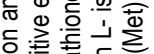

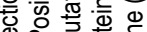

응 흥흔든

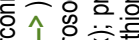

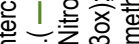

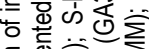

웡

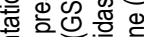

这

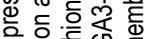

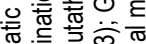

뜰

过

क 믕휴 잉

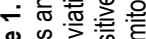

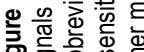

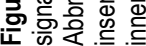


species but different from those of DNA ligases I, III and IV (Waterworth et al., 2010). In desiccated seeds, DNA damage is repaired on the initiation of imbibitions that is perceived as a promising phenomenon in enhancing life tenure and germination percentage of seed (Balestrazzi et al., 2011). Waterworth et al. (2010) reported that a mutant of the plant-specific DNA ligase 6 gene (AtLIG6) exhibited a delayed seed germination phenotype. Protein primary structure analysis revealed that the $\beta$-CASP motif of the AtLIG6 Nterminal region is present in a number of repair enzymes, and moreover, double mutants of AtLIG4 and AtLIG6 and single mutants of AtLIG6 have been found to possess noteworthy hypersensitivity to seed aging and to exhibit reduced viability and delayed germination, compared to wild-type plants. These findings confirm that AtLIG6 is a main regulator of seed quality and longevity in Arabidopsis. In Medicago truncatula, the enzymes that repair oxidized DNA (e.g., formamidopyrimidine-DNA glycosylase and 8-oxoguanine DNA glycosylase/lyase) are upregulated during the initial stages of germination, which supports the importance of DNA repair during seed germination (Macovei et al., 2011). Moreover, the Arabidopsis knockout mutantnbs1 has verified that DNA repair subunit NBS1 controls telomeric homeostasis. Furthermore, until now, no signs of developmental aberrations have been noted in NBS1-deficient plants. However, they produce fertile and viable seeds in subsequent generations upon selffertilization (Najdekrova and Siroky, 2012), and intense developmental defects have been reported in double-mutant plants missing the functional telomerase till three generations. Cytogenetic inspection and molecular methods employed for the examination of telomere length in double homozygous mutants revealed a much rapid telomere contraction than in plants lacking telomerase gene. These observations confirm that $n b s 1$ and telomerase unanimously play vital roles in plant telomere renewal, which can also be important for seed viability. Nicotinamide functions as an inhibitor of poly (ADP-ribose) polymerases, which regulate DNA repair process. Therefore, it should be degraded during germination. The expression analysis of the nicotinamidase-encoding gene NIC2 in Arabidopsis has revealed that NIC2 is expressed at relatively higher rates in mature Arabidopsis seeds (Hunt et al., 2007). This is further supported by the analysis of an Arabidopsis NIC2-1 knockout mutant, in which seeds have diminished nicotinamidase activity and hampered germination. This observation suggests that NIC2 metabolizes nicotinamide, thus, accelerating poly(ADP-ribose) polymerases activity and initiating the DNA repair process (Hunt et al., 2007).

\section{Enzyme repair}

The aging process in living organisms is related to DNA damage, as well as protein dysfunction. Spontaneous damage of proteins during cell aging is attributed to the generation of abnormal amino acid residues. The protein L-isoaspartyl methyltransferase (PIMT) catalyzes the transformation of abnormal L-isoaspartyl and L-isoasparaginyl residues to their normal L-aspartyl and L-asparaginyl forms, thus mitigating protein misfolding owe to isomerized aspartyl (Asp) and asparaginyl (Asn) residues formation. Moreover, the proteins of a variety of organisms are spontaneously enriched by residual accumulation of isomerized aspartyl and asparaginyl residues. Therefore, the PIMT repair enzyme system plays a vital role in the survival and longevity of organisms in the animal and bacterial kingdoms (Clarke, 2003). However, alteredPIMT1 expression in Arabidopsis lines validates its role as a main endogenous dynamic controlling anomalous deposition of L-isoaspartyl in seed proteins, thus, enhancing seed vigor and longevity (Oge et al. 2008). Other anti-ageing pathways and PIMT repair pathway work unanimously to eradicate hazardous protein outcomes, thus ensuring the successful establishment of seedlings. Recently, PIMT2 was reported to have a similar function as PIMT1 in both Arabidopsis and chickpea. The major difference is their localization, with PIMT1 functioning in the cytosol and PIMT2 in the nucleus (Verma et al., 2013). In dehydrated orthodox seeds, proteins spontaneously degrade into succinimide derivatives of Asp and Asn residues, which are isomerized upon imbibition into derivatives of isoAsp (Nayak et al., 2013), which is deleterious to appropriate protein function and, if unrepaired, will compromise seed vigor. Although PIMT mediates isoAsp transformation to Asp residues, proteins associated with translation upon imbibitions in orthodox seeds are still critically important to sustain the seeds in the active state. PLANT RNA HELICASE 75 (PRH 75), which is also known as Dead-box helicase, exhibits susceptibility to isoAsp residual deposition, as traced in Arabidopsis thaliana. This confirms that PIMT repairs $\mathrm{PRH} 75$ via isoAsp conversion to Asp residues, coupled with seed vigor restoration. In most plant species, seeds possess reduced PIMT activity during germination. However, consistent PIMT activity in sacred lotus seeds minimizes the racemization of aspartyl in proteins; therefore, they possess exceptional longevity (Shen-Miller, 2002). 


\section{Epigenetic regulation and telomere length}

Epigenetics demonstrates heritable variations in genes expression or cellular phenotypes without any change in sequential architect of DNA. Epigenetic modulation of gene manifestation is destined by histone variants, histone modifications, chromatin remodeling, DNA methylation, and may involve small RNAs (Ahmad et al., 2010). In recent years, epigenetics has become one of the most exciting areas in functional genomics. In higher plants, seed germination and vigor are associated with the expression of a great number of genes and are related to various epigenetic processes.

\section{DNA methylation}

In genomic DNA, methylation of fifth carbon of cytosine (5-methylcytosine) is frequently linked with heterochromatic loci comprising centromeres and telomeres and is also concurrent with various silent loci, especially transposable elements and repetitive sequences (Lu et al., 2006; Le et al., 2007; Bauer and Fisher, 2011). The involvement of DNA methylation in the seed germination process was confirmed through methylation-sensitive amplification polymorphisms (Portis et al., 2004; Meng et al., 2012).

In the seeds and seedlings of pear (Pyrus communis), DNA methylation has been reported to increase as the moisture level declined $2.3 \%$, whereas DNA methylation was reduced when the moisture content increased to $5.3 \%$ (Michalak et al., 2013). Moreover, significantly increased DNA methylation has been reportedin seeds under storage period of one year (Singh et al., 2013). These results suggest the possibility of seed aging coupled with increased DNA methylation. The inhibitory effects of DNA methylation on seed germination have also been reported in Arabidopsis, in which JMJ20 and JMJ22 (histone arginine demethylases) serve as redundant positive mediators of germination. The zinc finger-protein SOMNUS directly represses JMJ20/JMJ22 during the inactivation period of phytochrome $\mathrm{B}$ (PHYB). However, a boost in gibberellic acid level is detected during PHYB activation and JMJ20/JMJ22 depreciation, as a result of the excision of repressive histone arginine methylations from GA3ox1/GA3ox2, which accelerates the germination process (Cho et al., 2012). More recently, it has been disclosed that the modulated DNA methylation of two wheat genes (i.e. AGO802 and AGO804), which are differentially expressed in the embryos of developing seeds, were related to pre-harvest sprouting (Singh et al., 2013). Along with DNA methylation, histone methylation is also of pivotal importance to seed viability. Moreover, epigenetic states catalyzing histone $\mathrm{H} 3$ lysine 27 trimethylation (H3K27me3) being a repressive chromatin mark has polycomb repressive complex (PRC2) as a key regulator. Bouyer et al. (2011) reported that transitions from embryonic to seedling phases and from vegetative to flowering phases are controlled by robust PRC2-mediated regulation via histone methylation. Müller et al. (2012) also confirmed the function of PRC2 and H3K27me3 in seed germination. The authors reported that this mode of action, histone methylation/demethylation, together with $A B I 3$, was evolutionarily conserved from gymnosperms to angiosperms. A significant feature of aging is associated with telomeres, the repetitive sequence of nucleotides situated at each terminus of chromatid, which protects the terminus from deterioration or from fusion with adjacent chromosomes, thus preserving genomic integrity. Likewise animal cells, dynamicity of plant telomeric DNA determines morphological variations during aging and differentiation (Kilian et al., 1995). Despite having identical germination rates, significant differences in telomeric lengths were reported in both fresh and stored wheat seeds (Bucholc and Buchowicz, 1992; Bucholc and Buchowicz, 1995). Various studies have reported a strong association between aging and telomere length, as indicated by the breakdown of telomeric sequences (Boubriak et al., 2007). Dona et al. (2013) also found that the telomeric length of seeds from two alpine species, Silene acaulis and Silene vulgaris, decreased and increased significantly upon drying and rehydration, respectively. Under artificial aging conditions, seeds of both species exhibit significant reductions in telomere length. Moreover, in the chromosomes of dry seeds, the restoration of telomere ends occurs through the initiation of telomerase activity (Riha et al., 1998). Balestrazzi et al. (2010) suggested that increases in telomere length at the initial stage of imbibition are associated with seed repair processes, which are catalyzed to eliminate DNA fragments. Moreover, under longterm storage, dried wheat embryos were devoid of telomeric repeats. However, fortification was observed at the early stage of imbibition (Bucholc and Buchowicz, 1992). There are certain reports that describe the impact of fluctuated telomeric homeostasis on seed vigor and viability, which may validate the link between genotoxicity and increased telomeric length. For example, impaired seed germination was reported in the Arabidopsis rtbp1 (rice telomere binding protein1) mutant, owing to increased telomeric length, as compared to wild- 
type plants (Hong et al., 2007). Similarly, an Arabidopsis mutant lacking ku70 function, which is required for telomere maintenance, exhibited increased telomere length, with a high susceptibility to genotoxicity (Riha et al., 2002). Currently, a framework is devised in plant and animal cells, where exogenous or endogenous oxidative damages to telomeres can be distinctly identified, owing to differentially induced responses (Wang et al., 2010). Therefore, it can be concluded that damages resulting from extrinsic factors contribute to telomere degradation. However, moderate injuries caused by cellular metabolism promote telomere lengthening. This model can be applied to seeds where telomeric degradation might be associated with artificial aging, whereas increased telomere length might be expected after rehydration, as a result of resumed metabolic processes.

\section{Micro RNA (miRNA) and argonaute (AGO)}

Recently, small RNAs, particularly miRNAs, have become a key research area in molecular biology and genomics. miRNAs of 20-24 nucleotides in length are usually transcribed from non-coding regions of the genome. RNA polymerase II transcribes precursors yield single-stranded precursors upon excision are known as miRNAs. These precursors construct stem-loop secondary structures, owing to the presence of selfcomplementary regions that are recognized by DCL1 proteins and converted into miRNA:miRNA* (Park et al., 2002). Moreover, ARGONAUTE (AGO) protein associates with miRNA in duplex to form RNA induced silencing complex, where miRNA base pairs with complementary sequence in target mRNA to direct its post-transcriptional regulation via translational repression or cleavage (Jeong et al., 2013). The involvement of miRNAs in the regulation of gene expression has been known for many years; however, their regulatory function at translational levels has only recently been discovered ( $\mathrm{Li}$ et al., 2013). Martin et al. (2005, 2006) first described the function of miRNA in Arabidopsis seeds. miRNAs 159 and 160 are thought to be involved in seed germination (Reyes and Chua, 2007; Liu et al., 2007; Table 2).

Various AGO genes from Arabidopsis (10) and rice (19) have been reported to function as effectors in RNA-induced silencing, but their function in plants, particularly in seeds, largely remains unclear (Rogers and Chen, 2013; Yang et al., 2013). Mallory and Vaucheret (2010) summarized the expression mode of AGO genes in Arabidopsis. The authors suggested that AGO1, AGO2, AGO3, AGO5, AGO6,
AGO7, AGO9, and AGO10aresignificantlyexpressed in seeds, andYang et al. (2013) reported that, during rice seed germination (72 $\mathrm{h}$ after imbibition), AGO1a, AGO1b, AGO1c, AGO2, AGO4a, AGO4b, $A G 07, A G 016, A G 018$, and PNH1were significantly expressed, with AGO4b, AGO4a, and AGO1a exhibiting the highest expression levels.

Recently, two AGO genes (TaAGO1b and TaAGO4) were cloned and characterized from common wheat (Liu et al., 2011; Meng et al., 2013). Interestingly, the genes were only differentially expressed in the endosperm during germination and were ubiquitously expressed in embryonic tissues. Similarly, in the endosperm of germinating wheat seeds (6 $\mathrm{h}$ after imbibition), the transcript level of TaAGO4 was reported to decline, which suggests the possible involvement of miRNA in seed germination and viability (Meng et al., 2013).

\section{Genomic tools for monitoring seed aging}

The above-mentioned information indicates that currently available methods in cell biology, biochemistry, and genomics can be used to monitor seed aging at various stages. Genomics (including functional genomics) has played a major role in current biological research(Kujoth et al., 2005). In contrast to genetics or molecular biology, which focuses on individual genes, genomics allow researchers to investigate the structure and function of entire gene families and genomes. Due to the rapid progress in plant genomics, large numbers of genes and regulators have been revealed to be associated with seed germination and viability (Ding et al., 2013). Therefore, the new knowledge from genomics can be used for the development of seed biotechnology. Furthermore, some new technologies, such as next generation sequencing (NGS), are particularly efficient for studying seed deterioration.

Next-generation sequencing technology, including 454, Illumina, and SOLiD, has recently become a key approach in molecular biology and genomics. The technology is high throughput, low cost, reliable, and precious qualification(Shah et al., 2017) and can be used for characterizing genomic DNA, mitochondrial DNA, mRNA, and small RNA (Ansorge, 2009). So far, NGS has been reported to provide better assessments of seed deterioration (Chaudhury et al., 2001; Fu and Peterson, 2012), and to the best of our knowledge, NGS technology can be utilized in the following types of research. 


\section{Transcriptomics}

Seed aging is coincident with transcriptome alternation, which can be investigated using NGS, and the effects of seed priming and stress treatment can be identified by characterizing the corresponding transcriptomes.

\section{Mitochondrial genomic alternation}

Mitochondrial genomes are much smaller than nuclear genomes. When mitochondrial genomes are exposed to ROS, mitochondrial genome alternation has been proposed to contribute to seed aging. Thus, it is logical to consider using NGS to investigate mitochondrial genome alternation in aging seeds.

\section{miRNA transcriptomics}

Quite a few types of miRNA are involved in the process of seed germination. Using NGS, the alternation of miRNA trancriptomes in aging seeds can be clearly identified (Table 2).

\section{Genomic methylation analysis}

The methylation state of a whole genome, or methylome, has been measured at single-base resolution using bisulfite conversion of genomic DNA, combined with NGS (BS-seq; Krueger et al., 2012). This strategy could also be used to monitor seed aging in the future, especially for the mitochondrial genome (Lu et al., 2006; Birtic et al., 2011). DNA methylation has been implicated inthe seed germination process, using methylation sensitive amplification polymorphisms (Portis et al., 2004; Meng et al., 2012). Therefore, to characterize DNA methylation during seed aging, methylationsensitive amplification polymorphisms may serve as a new tool. From the polymorphic data of DNA methylation from aging seeds, we can measure seed viability.

Seed aging can also be assessed by measuring genomic DNA methylation via investigation of the genome's global m5C content, which can be accomplished using thin-layer chromatography or high pressure liquid chromatography (HPLC). However, thin-layer chromatography is more feasible, since a smaller amount of DNA is needed to differentiate ribo- and deoxyribonucleotides under experimental analysis (Michalak et al., 2013).

Table 2. Summary of miRNAs related to seed germination and post germination transition.

\begin{tabular}{|c|c|c|c|}
\hline miRNA & Target Gene & Plant Source & Authors and Year \\
\hline $\begin{array}{l}\operatorname{miR} 156 \\
\operatorname{miR} 156 a\end{array}$ & $\begin{array}{ll}\text { SPL13, } & \text { SBP } \\
\text { domain } & \\
\text { protein, } & \\
\end{array}$ & $\begin{array}{l}\text { Arabidopsis, Lotus Japonica } \\
\text { Maize, Brassica napus }\end{array}$ & $\begin{array}{l}\text { Martin et al., } 2010 \text {; Hu et al., } 2013 \text {; Ding et al., } \\
2012 \text {;Li et al., } 2013 \text {; Huang et al., } 2013\end{array}$ \\
\hline $\operatorname{miR} 159$ & $\begin{array}{l}\text { MYB33 and } \\
\text { MYB101, }\end{array}$ & Arabidopsis, Maize & Reyes and Chua, 200; Li et al., 2013 \\
\hline $\begin{array}{l}\operatorname{miR} 160 \\
\text { miR160a }\end{array}$ & ARF10 & Arabidopsis, Lotus Japonica & Liu et al., 2007 ; Hu et al., 2013 \\
\hline miR164 & NAC1 & Maize & Ding et al., 2012 ;Li et al., 2013 \\
\hline $\operatorname{miR} 166$ & HD-ZIP & Maize & Li et al., 2013 \\
\hline $\operatorname{miR} 167$ & ARF & Maize & Li et al., 2013 \\
\hline $\operatorname{miR} 168$ & $\begin{array}{l}\text { Argonaute1 } \\
\text { (At1g48410) }\end{array}$ & Arabidopsis, Maize & $\begin{array}{l}\text { Ding et al., 2012; Li et al., } 2013 \text {; Baldrich et } \\
\text { al., } 2014\end{array}$ \\
\hline $\operatorname{miR} 169$ & NFY, & Maize & Ding et al., $2012 ;$ Li et al., 2013 \\
\hline $\operatorname{miR} 172$ & SNZ; & Arabidopsis, Maize & Martin et al., 2010 ;Li et al., 2013 \\
\hline $\operatorname{miR} 319$ & MYB, & Maize & Li et al., 2013 \\
\hline miR393 & TIR1-like, & Maize & Li et al., 2013 \\
\hline miR394 & LCR & Maize; Arabidopsis & Li et al., 2013 ; Song et al., 2016 \\
\hline $\begin{array}{l}\text { miR395c; } \\
\text { miR395e }\end{array}$ & APS & Arabidopsis & Kim et al., 2010 \\
\hline miR396 & GRFs, & Maize & Ding et al., 2012 \\
\hline $\operatorname{miR} 397$ & LCR & Maize & Li et al., 2013; \\
\hline miR398 & $?$ & Maize & Li et al., 2013 \\
\hline miR399a & $?$ & Lotus Japonica & Hu et al., 2013 ; Song et al., 2016 \\
\hline miR408 & $\begin{array}{c}\text { plantacyanin } \\
\text { Cupredoxin }\end{array}$ & Arabidopsis, Maize & Li et al., 2013 : Ding et al., 2016 \\
\hline miR528 & $\mathrm{CSD} / \mathrm{CPD}$ & Maize & Li et al., 2013 \\
\hline $\operatorname{miR} 529$ & $?$ & Maize & Li et al., 2013 \\
\hline
\end{tabular}


Moreover, qRT-PCR has been used to study the transcript level of some regulatory and functional genes involved in seed germination (Liu et al., 2011; Feshani et al., 2012; Hu et al., 2013; Meng et al., 2013). The alternation of transcript levels of some germination-required genes in aging seeds can be detected using qRT-PCR. Thus, some sensitive genes, e.g., AGO genes, miRNA, anti-oxidative genes can serve as biomarkers for seed aging by using qRT-PCR.

As described above, DNA repair (Waterworth et al., 2010; Najdekrova and Siroky 2012), enzyme repair (Oge et al.2008; Nayak et al., 2013), and antioxidation genes (Yao et al., 2012) are all reported to influence seed viability. In order to develop new tools for monitoring seed aging, qRT-PCR can be used to inspect the expression level of related antioxidative genes (Dona et al., 2013). Recently, Hu et al. (2012) reported that controlled deterioration treatment immediately invokes significant increases in caspase-3/DEVDase proteolytic activity. Therefore, qRT-PCR can also be used to detect the expression of the protein in stored seeds.

In addition, since the early of 1990's, telomere shortening has been implicated in cell aging in almost all types of living organisms, including plants (reviewed by Watson and Riha, 2011). Seed aging was assessed effectively by measuring the length of telomeres in seeds (Boubriak et al., 2007; Dona et al., 2013). Therefore, telomeric investigation has been proposed as a reliable marker of seed aging, and both Southern blotting and QRT-PCR have been used for telomere length analysis (Boubriak et al., 2007; Dona et al., 2013).

\section{Molecular markers}

DNA alternation has been reported to trigger PCD during seed deterioration (Liu et al., 2005; Hu et al., 2012). The two basic strategies used to detect DNA alternation efficiently are the identification of DNA laddering, using electrophoreses, and the identification of DNA alteration, using RAPD markers. In various studies, the use of RAPD has been recommended as an appropriate procedure to detect DNA damage and mutational events, including point mutations, insertions, structural rearrangements, deletions, and other possible changes, such as structural distortion (Atienzar and Jha, 2006; El-Maarouf-Bouteau et al., 2011). Quantitative trait loci associated with seed longevity have been thoroughly investigated, in order to elucidate the genetic basis of seed deterioration (Shatters et al., 1995; Arif et al., 2012). As a result of these efforts, genes that govern seed longevity have been identified and may facilitate the prediction of the longevity in plant germplasm repertoires (Nagel et al., 2009; Vijay et al., 2009). For example, four genomic regions associated with wheat seed longevity are known to include genes related to stress responses and spike traits (Arif et al., 2012). These outcomes are encouraging, since the prediction of seed viability will facilitate the improvement monitoring of stored seeds.

To fully utilize the increasing amounts of high-quality genome-wide transcriptomic data associated with seed viability and aging, novel analytical tools are needed. For example, the co-expression analysis approach, which was used in $A$. thaliana to undermine gene functions engaged in the mediation of seed germination (Bassel et al., 2011a), can also be applied to the functionality of genes involved in the regulation of seed aging. Along with coexpression analysis, Bassels et al. (2011b) recently proposed that co-prediction analysis, which allows the prediction of functional gene associations that would not be identified via co-expression analysis. With co-prediction analysis, microarray data set under different physiological conditions, such asconditions under storage and germination, can be used. Conventional transcript analysis has continuouslyfailed to detect specific coordination during aging regulated by common cis-elements and trans-factors; however, co-prediction could be an effective tool (Bassel et al., 2011b). During the aging of pea seeds, PCD is associated with changes in the half-cell reduction potential of the major cellular antioxidant and redox buffer glutathione [E(GSSG/2GSH)] (Kranner et al., 2006). Similarly, Birtic et al. (2011) hypothesized that the half-cell reduction potentials of low molecular weight cysteine, thiols, g-glutamyl-cysteine, and cysteinylglycine can be potentially used as markers for seed aging (Table 3).

\section{Prospects}

Although seed deterioration is an active area of research,its complex dynamics are poorly understood. Seed aging is a complex physiological process. It is difficult to search for signals from various stages to predict the status of seed viability. This review reveals several interesting signals that could be utilized to monitor seed viability. These signals include ROS- and mitochondrial-triggered PCD in aging seeds, the transcription of antioxidative and DNA and protein repair genes, telomere length, the expression of epigenetic regulation-related genes (miRNA and methylation), 
Table 3. Summary of functional genomic marker genes related to seed viability.

\begin{tabular}{|c|c|c|c|}
\hline Gene & Functional Protein & Plant Source & Authors \\
\hline$A P X$ & Ascorbate peroxidase & Pea, Triticum aestivum & Yao et al., 2012 ; Padaria et al., 2014 \\
\hline CAT & Catalase & Pea & Yao et al., 2012 \\
\hline GR & Glutathione reductase & Pea, Arabidopsis & $\begin{array}{l}\text { Yao et al., 2012; Yu et al., } 2013 \text {; } \\
\text { Ding et al., 2016. }\end{array}$ \\
\hline$S O D$ & Superoxidate dismutase & $\begin{array}{l}\text { Pea, Silene vulgaris, } \\
\text { Silene acaulis }\end{array}$ & Yao et al., 2012; Dona et al., 2013 \\
\hline MT2 & Type 2 metallothionein & $\begin{array}{l}\text { Pea, Soybean, Silene } \\
\text { vulgaris, Silene acaulis }\end{array}$ & Dona et al., 2013 \\
\hline Atlig6 & DNA ligase VI & Arabidopsis & $\begin{array}{l}\text { Wateworth et al., et al., 2010; } \\
\text { Furukawa et al., } 2015\end{array}$ \\
\hline$N B S 1$ & DNA repair subunit on telomere & Arabidopsis & $\begin{array}{l}\text { Oge et al., } 2008 ; \text { Najdekrova and } \\
\text { Siroky, } 2012\end{array}$ \\
\hline PIMT1 & L-isoaspartyl methyltransferase & Arabidopsis & $\begin{array}{l}\text { Nayak. et al., } 2013 \text {; Verma et al., } \\
2013\end{array}$ \\
\hline PIMT2 & L-isoaspartyl methyltransferase & $\begin{array}{l}\text { Arabidopsis, Chick- pea, } \\
\text { Silene vulgaris, } \\
\text { Silene acaulis }\end{array}$ & Dona et al., 2013 \\
\hline $\begin{array}{l}\text { At3g0803 } \\
0\end{array}$ & $\begin{array}{l}\text { cell-wall-associated } \\
\text { protein }\end{array}$ & $\begin{array}{l}\text { Arabidopsis, } \\
\text { Ceiba aesculifolia, } \\
\text { Wigandia urens }\end{array}$ & Garza-Caligaris et al., 2012 \\
\hline
\end{tabular}

and alternations in mitochondrial and nuclear genome sequences. Among these approaches, genomic tools may be more effective, since genomic signals can be detected directly and clearly, whereas PCD analysis, such as TUNEL, is time consuming, complex, and indirect.

It seems that NGS has opened many avenues to assess the genetic changes that occur during seed development and exhibits the most promise for the development of effective tools to monitor seed viability. Next-generation sequencing can be used to investigate the transcriptome of aging seeds, which can elaborate the multiple aging related genomic signals (including anti-oxidative genes, DNA and enzyme repair genes, miRNA related genes, and telomeres), and can be used to analyze sequence mutations in both mitochondrial and nuclear genomes, as well as epigenetic process, by characterizing small RNA and methylation alternation in aging seeds. For all these, the cost of NGS is much lower than that of Sanger sequencing and provides much more information. Therefore, searching for effective tools to monitor seed viability may provide advances in the assessment of seed viability and provide a useful supplement to the traditional methods of germination testing for the long-term conservation of ex-situ plant germplasm.

\section{Acknowledgements}

The authors are highly grateful to $\mathrm{Dr}$. Yong-Bi Fu and Dr. Yan Zhang for their help and comments on earlier versions of this review.

\section{References}

Ahmad, A., Zhang, Y., and Cao, X.F. (2010). Decoding the epigenetic language of plant development. Molecular Plant. 3(4), 719-728.

Ansorge, W.J. (2009). Next-generation DNA sequencing techniques. New Biotechnolog. 25, 4 195-203.

Arif. M.A., R., Nagel, M., Neumann, K., Kobiljski, B., Lohwasser, U., and Borner, A. 2012.Genetic studies of seed longevity in hexaploid wheat using segregation and association mapping approaches. Euphytica 186(1), 1-13.

Astegar, Z.R., Sedghi, M., Khomari, S. (2011). Effects of accelerated aging on soybean seed germination indexes at laboratory conditions. Not. Sci. Biol. 3(3), 126-129.

Atienzar, F.A., Jha, A.N. (2006). The random amplified polymorphic DNA (RAPD) assay and related techniques applied to genotoxicity and 
carcinogenesis studies: a critical review. Mutation Research613, 76-102.

Atlante, A., Gagliardi, S., Minervini, G.M., Marra, E., Passarella, S., Calissano, P. (1996). Rapid uncoupling of oxidative phosphorylation accompanies glutamate toxicity in rat cerebellar granule cells. Neuroreport 7, 2519-2523.

Bailly, C., Benamar, A., Corbineau, F., Co^me, D. (1996). Changes in malondialdehyde content and in superoxide dismutase, catalase and glutathione reductase activities in sunflower seeds as related to deterioration during accelerated aging. Physiol. Plant. 97, 104-110.

Bailly, C. (2004). Active oxygen species and antioxidants in seed biology. Seed Sci. Res. 14, 93-107.

Baldrich, P., Kakar, K., Siré, C., Moreno, A.B., Berger, A.Q., García-Chapa, M., LópezMoya, J.J., Riechmann, L.J., Segundo, B. (2014). Small RNA profiling reveals regulation of Arabidopsis miR168 and heterochromatic siRNA415 in response to fungal elicitors. BMC Genomics 15, 1083.

Balestrazzi, A., Botti, S., Zelasco, S., et al. (2009). Expression of the PsMTA1 gene in white poplar engineered with the MAT system is associated with heavy metal tolerance and protection against 8-hydroxy-2'-deoxyguanosine mediated-DNA damage. Plant Cell Rep. 28, 1179-1192.

Balestrazzi, A., Confalonieri, M., Macovei, A., Carbonera, D. (2010). Seed imbibition in Medicago truncatula Gaertn.: expression profiles of DNA repair genes in relation to PEG-mediated stress. J. Plant Physiol. 168, 706-713.

Balestrazzi, A., Confalonieri, M., Macovei, A., Dona, M., and Carbonera, D. (2011). Genotoxic stress and DNA repair in plants: emerging functions and tools for improving crop productivity Plant Cell Rep.30, 287-295

Barba-Espin, G., Diaz-Vivancos, P., Job, D., Belghazi, M., Job, C., Hernandez, J.A. (2011).Understanding the role of $\mathrm{H} 2 \mathrm{O} 2$ during pea seed germination: a combined proteomic and hormone profiling approach. Plant Cell Environ. 34, 1907-19.

Bassel, G.W., Glaab, E., Marquez, J., Holdsworth, M.J., Bacardit, J. (2011b). Functional network construction in Arabidopsis using rule-based machine learning on large-scale data sets, Plant Cell23, 3101-3116.

Bassel, G.W., Lan, H., Glaab, E., Gibbs, D.J., Gerjets, T., Krasnogor, N., Bonner, A.J., Holdsworth, M.J., Provart, N.J. (2011a). Genomewide network model capturing seed germination reveals coordinated regulation of plant cellular phase transitions. Proc. Natl. Acad. Sci. 108(23), 9709-14.

Bauer, M.J., and Fischer, R.L. (2011). Genome demethylation and imprinting in the endosperm Curr. Opin. Plant Biol. 14,162-167.

Benamar, A., Tallon, C., and Macherel, D. (2003). Membrane integrity and oxidative properties of mitochondria isolated from imbibing pea seeds after priming or accelerated ageing. Seed Sci. Res.13, 35-45.

Berjak, P. (1997). Parmenter, Progress in understanding and manipulation of dessicationsensitive (recalcitrant) seeds, in: R.H. Ellis, M. Block, A.J. Murdoch,H.D. Hong (Eds.), Basic and Applied Aspects of Seed Biology, Kluwer Academic Publishers, The Netherlands, pp. $689 \mathrm{e} 703$.

Biabani, A., Boggs, L.C., Katozi, M., Sabouri, H. (2011). Effects of seed deterioration and inoculation with Mesorhizobiumcicerion yield and plant performance of chickpea. Aus. J. Crop Sci. 5 (1), 66-70.

Birtic, S., Colville, L., Pritchard, H.W., Pearce, S.R., Kranner, I. (2011). Mathematically combined halfcell reduction potentials of the low-molecularweight thiols as markers of seed aging. Free Radic. Res. 45, 1093-1102.

Boubriak, I., Dini, M., Berjak, P., Osborne, D.J. (2000). Dessication and survival in the recalcitrant seeds of Avicennia marina: DNA replication, DNA repair and protein synthesis, Seed Sci. Res. 10, 307-315.

Boubriak, I., Polischuk, V., Grodzinsky, A., and Osborne, D.J. (2007). Telomeres and seed banks Cytol. Genet.41, (1) 18-24.

Bouyer, D., Roudier, F., Heese, M., Andersen, E.D., Gey, D., Nowack, M.K., Goodrich, J., Renou, J.,Grini, P.E., Colot, V., Schnittger, A. (2011). Polycomb Repressive Complex 2 Controls the Embryo-to-Seedling Phase Transition. PLoS Genet. 7(3), e1002014.

Bove, J., Jullien, M., and Grappin, P. (2001). Functional genomics in the study of seed germination. Genome Biology 3(1), 1002.1-1002.5.

Bras, M., Queenan, B., Susin, S.A. (2005). Programmed cell death via mitochondria: different modes of dying. Biochemistry 70, 231-239.

Bucholc, M., Buchowicz, J. (1992). Synthesis and extrachromosomal DNA and telomere-related sequences in germinating wheat embryos. Seed Sci. Res. 2, 141-144.

Buitnik, J., Hoekstra, F.A., Leprince, O. (2002), Biochemistry and biophysics of tolerance systems, in: M. Black, H.W. Pritchard (Eds.), 
Dessication and Survival in Plants. Drying without Dying, CABI Publishing, Wallington, Oxon, pp, 293-318.

Cao, J., Lv, X.Y., Chen, L., Xiang, J.J., and Lan, H.Y. (2015). Effects of salinity on the growth, physiology and relevant gene expression of an annual Halophyte grown from heteromorphic seeds. AoB Plants 7, plv112.

Cash, T.P., Pan, Y., Simon, M.C. (2007). Reactive oxygen species and cellular oxygen sensing. Free Radic. Biol. Med. 43, 1219-1225.

Chaudhury, A.M., Koltunow, A., Payne, T., Luo, M., Tucker, M.R., Dennis, E.S., and Peacock, W.J. (2001). Control of barley seed development. Annu. Rev. Cell Dev.l Biol. 17, 677-699.

Chauhan, D.S., Deswal, D.P., Dahiya, O.S., and Punia, R.C. (2011).Change in storage enzymes activities in natural and accelerated aged seed of wheat (Triticum aestivum).Indian J. Agric. Sci. 81(11), 1037-40

Cheah, K.S.E., Osborne, D.J. (1978). DNA lesions occur with loss of viability in embryos of ageing rye seeds. Nature 272, 593-599.

Chmielowska, B.,Ak, J., Izbianska, K., and Deckert, J. (2015). Products of lipid, protein and mRNA oxidation as signals and regulators of gene expression. Front. Plant Sci. 6, 405.

Cho, J.N., Ryu, J.Y., Jeong, Y.M., Park, J., Song, J.J., Amasino, R.M., Noh, B., and Noh, Y.S. (2012). Control of seed germination by lightinduced histone arginine demethylation activity.Developmental Cell 22, 736-748

Chwedorzewska, K.J., Bednarek, P.T., Puchalski, J., and Krajewski, P. (2002). AFLP-profiling of longterm stored and regenerated rye genebank samples.Cellular Mol. Biol. Lett. 7(2 A), 457-463.

Calderwood, A., and Kopriva, S. (2014). Hydrogen sulfide in plants, from Dissipation of excess sulfur to signaling molecule. Nitric Oxide 41, 72-78.

Clarke, S. (2003).Aging as war between chemical and biochemical processes: Protein methylation and the recognition of age-damaged proteins for repair. Ageing Research Reviews2(3), 263-285.

Coolbear, P. (1995). Mechanism of seed deterioration. In Seed Quality: Basic Mechanisms and Agricultural Implications (Basra, A.S., eds). New York: Food Product Press, pp, 223-277

Corbineau, F. (2012). Markers of seed quality: from present to future. Seed Sci. Res. 22, S61-S68

Corbineau, F., Gay-Mathieu, C., Vinel, D., Co^me, D. (2002). Decrease in sunflower (Helianthus annuus) seed viability caused by high temperature as related to energy metabolism, membrane damage and lipid composition. Physiol. Plant. 116, 489-496.
De Gara, L., de Pinto, M.C., Arrigoni, O. (1997). Ascorbate synthesis and ascorbate peroxidase activity during the early stage of wheat germination. Physiol. Plant. 100, 894-900.

Diaz-Vivancos, P., Barba-Espı'n, G., and Herna 'ndez, J.A. (2013). Elucidating hormonal/ROS networks during seed germination: insights and perspectives. Plant Cell Rep. 32, 1491-1502.

Diaz-Vivancos, P., Barba-Espín, G., Hernández, J.A. (2013). Elucidating hormonal/ROS networks during seed germination: insights and perspectives. Plant Cell Rep, 32,1491-1502.

Ding, D., Wang, Y., Han, M., Fu, Z., Li, W., Liu, Z., Hu, Y., and Tang, J. (2013). MicroRNA Transcriptomic Analysis of Heterosis during Maize Seed Germination. PloS one7(6), e39578.

Ding, S., Jiang, R., Lu, Q., Wen, X., Lu, C. (2016). Glutathione reductase 2 maintains the function of photosystem II in Arabidopsis under excess light. Biochim. Biophys. Acta 1857 (6), 665-677.

Dona, M., Balestrazzi, A., Mondoni, A., Rossi, G., Ventura, L., Buttafava, A., Macovei, A., Sabatini, M.E., Valassi, A., and Carbonera, D. (2013). DNA profiling, telomere analysis and antioxidant properties as tools for monitoring ex situ seed longevity.Annals of Botany 111, 987-998.

Dulloo, M.E., Hunter, D., and Borelli, T., (2010). Ex situ and in situ conservation of agricultural biodiversity: major advances and research needs.Not. Bot. Horti. Agrobot. 38(2), 123-135.

El-Maarouf-Bouteau, H., Mazuy, C., Corbineau, F., and Bailly, C. (2011). DNA alteration and programmed cell death during ageing of sunflower seed. J. Exp. Bot. 62(14), 5003-5011.

El-Maarouf-Bouteau, H., Sajjad, Y., Bazin, J., Langlade, N., Cristescu, S.M., Balzergue, S., etal. (2015). Reactive oxygen species, abscisic acid and ethylene interact to regulate sun flower seed germination. Plant Cell Environ. 38, 364-374.

Fath, A., Bethke, P., Lonsdale, J., Meza-Romero, R., Jones, R. (2000). Programmed cell death in cereal aleurone. Plant Mol. Biol. 44, 255-266.

Feshani,A., Mohammadi, M.S., Frazier, T.P, Abbasi, A., Abedini, R., Farsad, L.K., Farveh, E., Salekdeh, G.H., and Mardi, M. (2012).Identification and validation of Asteraceae miRNAs by the expressed sequence tag analysis. Gene 493(2), 253-259.

Fu, Y.B. (2003). Application of bulking in molecular characterization of plant germplasm: a critical review. Plant Genet. Resour. 1(2-3), 161-167

Fu, Y.B., and Peterson, G.W. (2012). Developing genomic resources in two Linum species via 454 pyrosequencing and genomic reduction.Mol. Eco. Resour. 12, 492-500 
Fu, Y.B., and Somers, D.J. (2009).Genome-wide reduction of genetic diversity in wheat breeding Crop Sci. 49, 161-168

Fu, Y.B., Ahmed,Z., andDiederichsen,A.(2015). Towards a better monitoring of seed a geing under ex situ seed conservation. Conserv. Physiol. 3, 26.

Furukawa, T., Angelis, K.J., Britt, A.B. (2015). Arabidopsis DNA polymerase lambda mutant is mildly sensitive to DNA double strand breaks but defective in integration of a transgene. Front Plant Sci. 6, 357.

Garza-Caligaris, L.E., Avendano-Vazquez, A.O., and Alvarado-Lopez, S., Zuniga-Sanchez, E., OrozcoSegovia, A., Perez-Ruiz, R.V., Gamboa-deBuen, A. (2012). At3g08030 transcript: a molecular marker of seed ageing. Ann. Bot. 110, 1253-1260.

Ghassemi-Golezani, K., Bakhshy,J., Raey, Y.,d Hossainzadeh-Mahootchy, A. (2010). Seed vigor and field performance of winter oilseed rape (Brassica napus L.) Cultivars. Not. Bot. Hort. Agrobot. Cluj. 38(3), 146-150.

Guan, C., Wang, X., Feng, J., Hong, S., Liang, Y., Ren, B.,etal. (2014). Cytokinin Antagonizes abscisic acid-mediated inhibition of cotyledon greening by Promoting the degradation of abscisic acid insensitive protein in Arabidopsis. Plant Physiol. 164, 1515-1526.

Hancock, J.T., Whiteman, M. (2014).Hydrogen sulfide and cell Signaling, team player or referee? Plant Physiol. Bio chem. 78, 37-42.

Hancock, J.T., Whiteman, M. (2015). Hydrogen sulfide signaling, interactions with nitric oxide an dreactive oxygen species. Ann. N.Y. Acad. Sci.

Hengartner, M.O. (2000). The biochemistry of apoptosis. Nature 407, 770-776.

Hong, J.P., Byun, M.Y., Koo, D.H., An, K., Bang, J., In Kwon Chung, I.K., An, G., and Kim, W.T. (2007). Suppression of RICE TELOMERE BINDING PROTEIN 1 results in severe and gradual developmental defects accompanied by genome instability in rice. The Plant Cell 19, 1770-1781.

Hossain, M.A., Bhattacharjee, S., Armin, S.M., Qian, P., Xin, W., Li, H.Y., et al. (2015). Hydrogen per oxide priming modulates abiotic oxidative stress tolerance, insights from ROS detoxification and scavenging. Front. Plant Sci. 6, 420.

Hussain, S., Zheng, M., Khan, F., Khaliq, A., Fahad, S., Peng, S., et al. (2015). Benefits of rice seed priming are offset permanently by prolonged storage and the storage conditions. Sci. Rep. 5, 8101.

Hu, D., Ma, G., Wang, Q., Yao, J., Wang, Y., Pritchard, H., and Wang, X. (2012).Spatial and temporal nature of reactive oxygen species production and programmed cell death in elm (UImuspumila L.) seeds during controlled deterioration.Plant Cell Environ.35, 2045-2059.

$\mathrm{Hu}$, J., Zhang, H., and Ding, Y. (2013). Identification of conserved microRNAs and their targets in the model legume Lotus japonicas.Journal of Biotechnology 164, 520- 524.

Huang $H$ and Song SQ (2013) Change in desiccation tolerance of maize embryos duringdevelopment and germination at different water potential PEG-6000 in relation to oxidative process. Plant Physiol. Biochem. 68, 61-70.

Hunt, L., Holdsworth, M.J., Gray, J.E. (2007). Nicotinamidase activity is important for germination. Plant J. 51, 341-51.

Jeong, D.H., Thatcher, S.R., Brown, R.S.H., Zhai, J., Park, S., Rymarquis, L.A., Meyers, B.C., and Green, P.J. (2013). Comprehensive investigation of microRNAs enhanced by analysis of sequence variants, expression patterns, ARGONAUTE loading, and target cleavage.Plant Physiol.162, 1225-1245.

Jin, Z., Pei, Y. (2015). Physiological implications of hydrogen sulfide in plants: Pleasant exploration behind its unpleasant odour. Oxid. Med. Cell. Longev. 397502.

Kalemba, E.M., Suszka, J., and Ratajczak, E. (2015).The role of oxidative stress in Determining the level of viability of black poplar(Populus nigra) seeds stored at Different temperatures. Funct. Plant Biol. 42, 630-642.

Kavianim, B. (2010). Cryopreservation by encapsulation-dehydration for long-term storage of some importantgermplasm: seed of lily [Lilium ledebourii (Baker) Bioss.], embryonic axe of persian lilac (Melia azedarach L.), and tea (Camellia sinensis L.). Plant OMICS 3(6), 177-182.

Khan, T.A., Yusuf, M., and Fariduddin, Q. (2015). Seed treatment with $\mathrm{H} 2 \mathrm{O} 2$ modifies net photosynthetic rate and antioxidant system in mung Bean (Vigna radiata L.Wilczek) plants. Isr. J. Plant Sci. 62, 167-175.

Kibinza, S., Vinel, D., Côme, D., Bailly, C., Corbineau, F. (2006).Sunflower seed deterioration as related to moisture content during ageing, energy metabolism and active oxygen species scavenging. Physiol. Plant. 128, 496-506.

Kilian, A., Stiff, C., Kleinhofs, A. (1995). Barley telomeres shorten during differentiation but grow in callus culture. PNAS, USA92, 9555-9559.

Kim, J.Y., Lee, H.J.,Jung, H.J.,Maruyama, K., Suzuki,N.,and Kang,H. (2010).Overexpression of microRNA395c or 395e affects differently the 
seed germination of Arabidopsis thaliana under stress conditions. Planta232(6), 1447-1454.

Koizumi, M., Kikuchi, K., Isobe, S., Ishida, N., Naito, S., Kano, H. (2008). Role of seed coat in imbibing soybean seeds observed by micro-magnetic resonance imaging, Ann. Bot. 102, 343-352.

Kranner, I., Birtic, S., Anderson, K.M., Prichard, H.W. (2006). Glutathione half-cell reduction potential: a universal stress marker and modulator of programmed cell death. Free Radic. Biol. Med. 40, 2155-2165.

Kranner, I., Colville, L. (2010). Metals and seeds: biochemical and molecular implications and their significance for seed germination. Environ. Exp. Bot. 72, 93-105.

Kranner, I., Minibayeva, F.V., Beckett, R.P., Seal, C.E. (2010). What is stress? Concepts, definitions and applications in seed science. New Phytologist 188, 655-673.

Krueger, F., Kreck, B., Franke, A., and Andrews, S.R.(2012). DNA methylome analysis using short bisulfite sequencing data. Nature Methods9, 145-151.

Kujoth, G.C., Hiona, A., Pugh, T.D., et al. (2005). Mitochondrial DNA mutations, oxidative stress, and apoptosis in mammalian aging. Science 309, 481-484.

Kumar, S.P. J., Prasad, S.R., Banerjee, R., and Thammineni, C. (2015). Seed birth to death, dual functions of reactive oxygen species in seed physiology. Ann. Bot.116, 663-668.

Law, S.R., Narsai, R., Taylor, N.L., Delannoy, E., Carrie, C., Giraud, E., Millard, A.H., Small, I., Whelan, J. (2012). Nucleotide and RNA metabolism prime translational initiation in the earliest events of mitochondrial biogenesis during Arabidopsis thaliana germination, Plant Physiol. 158, 1610-1627.

Le, B.H., Wagmaister, J.A., Kawashima, T., Bui, A.Q., Harada, J.J., and Goldberg, R.B. (2007). Using genomics to study legume seed development, Plant Physiol. 144,562-574.

Lee, Y.P., Baek, K.H., Lee, H.S., Kwak, S.S., Bang, J., Kwon, S.Y. (2010). Tobacco seeds simultaneously overexpressing $\mathrm{Cu} / \mathrm{Zn}$-superoxide dismutase and ascorbate peroxidase display enhanced seed longevity and germination rates under stress conditions. J. Exp. Bot. 61, 2499-2506.

Li, D., Wang, L., Liu, X., Cui, D., Chen, T.,Zhang, H., Jiang, C., Xu, C., Li, P., Li, S., Zhao, L., andChen, $H$. (2013). Deep sequencing of maize small RNAs reveals a diverse set of microRNA in dry and imbibed seeds. PLoS ONE,8(1) e55107.
Li, S., Liu, L., Zhuang, X., Yu, Y., Liu, X., Cui, X., Ji, L., Pan, Z., Cao, X., Mo, B., Zhang, F., Raikhel, N., Jiang, L., and Chen, X.M.(2013). MicroRNAs Inhibit the Translation of Target mRNAs on the Endoplasmic Reticulum in Arabidopsis. Cell 153, 562-574

Li, Z.G., and He, Q.Q. (2015). Hydrogen per oxide might be a downstream signal molecule of hydrogen sulfide in seed germination ofmungbean (Vigna radiata). Biologia 70, 753-759.

Linkies, A., Graeber, K., Knight, C., and LeubnerMetzger, G. (2010). The evolution of seeds, New Phytologist 86 (4), 817-831.

Liu, P.P., Montgomery, T.A., Fahlgren, N., Kasschau, K.D., Nonogaki, H., and Carrington, J,C. (2007) Repression of AUXIN RESPONSE FACTOR10 by microRNA160 is critical for seed germination and post-germination stages. The Plant Journal 52, 133-146.

Liu, T.L., Li, J.C., Gu, J.T., Lu, W.J., Guo, C.J., Li, R.J., and Xiao, K. (2011). Cloning and molecular characterization of TaAGO1, a member of argonaute gene family in wheat (Triticum aestivum L.). African Journal of Biotechnology 10(62), 13407-13417

Liu, W., Li, P.J., Qi, X.M., Zhou, Q.X., Zheng, L., Sun, T.H., Yang, Y.S. (2005). DNA changes in barley (Hordeum vulgare) seedlings induced by cadmium pollution using RAPD analysis. Chemosphere 61, 158-167.

Liu, Y., Korneef, M., Soppe, W.J.J. (2007). The absence of histone $\mathrm{H} 2 \mathrm{~B}$ monoubiquitination in the Arabidopsis hub1 (rdo-4) mutant reveals a role for chromatin remodelling in seed dormancy, Plant Cell 19, 433-444

Lo, Y.S., Cheng, N., Hsiao, L.J., Annamalai, A., Jauh, G.Y., Wen, T.N., Dai, H., and Chiang, K.S. (2011). Actin in mung bean mitochondria and implications for its function. The Plant Cell 23, 3727-3744

Lockshin, R.A., and Zakeri, Z. (2004). Apoptosis, autophagy, and more. Int. J. Biochem. Cell Biol. 36, 2405-2419

Logan, D.C., Millar, A.H., Sweetlove, L.J., Hill, S.A. and Leaver, C.J. (2001). Mitochondrial biogenesis duringgermination in maize embryos. Plant Physiol.125, 662-672.

Lu, G., Wu, X., Chen, B.,,G., Xu, K., and Li, X. (2006). Detection of DNA methylation changes during seed germination in rapeseed (Brassica napus). Chinese Science Bulletin 51(2), 182-190.

Macovei, A., Balestrazzi, A., Confalonieri, M., Faé, M., Carbonera, D. (2011). New insights on the barrel medic MtOGG1 and MtFPG functions in relation to oxidative stress response in planta and 
during seed imbibition. Plant Physiol. Biochem. 49, 1040-50.

Mallory, A., and Vaucheret, H. (2010). Form, function, and regulation of ARGONAUTE proteins. The Plant Cell 22, 3879-3889.

Mansfield, S.G., Briarty, L.G.(1992). Cotyledon cell development in Arabidopsis thaliana during reserve deposition. Can. J. Bot. 70,151-64.

Martin, R.C., Asahina, M., Liu, P.P., Kristof, J.R., Coppersmith, J.L., Pluskota, W.E., Bassel, G.W., Goloviznina, N., Nguyen, T.T., Martínez-Andújar, C., Arun Kumar, M.B., Pupel, P., and Nonogaki, H. (2010). The regulation of post-germinative transition from the cotyledontovegetativeleaf stages by microRNA-targeted SQUAMOSA PROMOTER BINDING PROTEIN LIKE13 in Arabidopsis. Seed Sci. Res. 20, 89-96.

Martin, R.C., Liu, P.P., and Nonogaki, H. (2005). Simple purification of small RNAs from seeds and efficient detection of multiple microRNAs expressed in Arabidopsis thaliana and tomato (Lycopersicon esculentum) seeds. Seed Sci. Res. 15, 319-328.

Martin, R.C., Liu, P.P., and Nonogaki, H. (2006).microRNAs in seeds: modified detection techniques and potential applications. Can. J. Bot. 84, 189-198.

Martin, R.C., Asahina, M., Liu, P.P., Kristof, J.R., Coppersmith, J.L., Pluskota, W.E.,Bassel,G.W., Goloviznina, N.A., Nguyen, T.T., MartínezAndújar,C.,Arun Kumar, M.B., and Pupel,P. (2010). The microRNA156 and microRNA172 gene regulation cascades at post-germinative stages in Arabidopsis. Seed Sci. Res.20(2), 79-87

Masetto, T.E., Faria, J.M.R., Davide, A.C., da Silva, E.A.R. (2008). Dessication tolerance and DNA integrity in Eugenia pleurantha O. Berg. (Myrtaceae) seeds, Rev. Bras. Sem. 30, 175-180

McDonald, M.B. (1999). Seed deterioration: physiology, repair and assessment. Seed Sci. Technol. 27, 177-237.

Meng, F.R., Jia, H.Y., Ling, N., Xue, Y.L., Liu, H., Wang, K., Yin, J., and Li, Y.C.(2013). Cloning and characterization of two Argonaute genes in wheat (Triticum aestivum L.). BMC Plant Biology 13, 18.

Meng, F.R., Li, Y.C., Yin, J,. Liu, H., Chen, X.J., Ni, Z.F., and Sun, Q.X. (2012).Analysis of DNA methylation during the germination of wheat seeds. Biol. Plantarum56 (2), 269-275

Michalak, M., Barciszewska, M. Z., Barciszewski, J., Plitta, B.P., and Chmielarz, P.(2013). Global changes in DNA methylation in seeds and seedlings of pyrus communis after seed desiccation and storage PLOS ONE 8 (8), e70693.
Miller, G., Coutu, J., Shulaev, V., Mittler, R.(2008) Reactive oxygen signalling in plants. In: Yang Z, editor. Annual plant reviews, volume 33: intracellular signalling in plants. Oxford: WileyBlackwell Publishing; . p. 189-201.

Morohashi, Y. (1986). Patterns of mitochondrial development in reserve tissues of germinated seeds: a survey. Physiol. Plant. 66, 653-658.

Müller, K., Bouyer, D., Schnittger, A., Kermode, A.R. (2012). Evolutionarily Conserved Histone Methylation Dynamics during Seed Life-Cycle Transitions. PLoS ONE 7(12), e51532.

Nagel, M., Vogel, H., Landjeva, S., Buck-Sorlin, G., Lohwasser, U., Scholz, U. et al. (2009).Seed conservation in ex situ genebanks-genetic studies on longevity in barley. Euphytica 170, 5-14.

Najdekrova, L., and Siroky, J. (2012). NBS1 plays a synergistic role with telomerase in the maintenance of telomeres in Arabidopsis thaliana. BMCPlant Biology 12, 167.

Nayak, N.R., Putnam, A.A., Addepalli, B., Lowenson, J.D., Chen, T., Jankowsky, E., Perry, S.E., Dinkins, R.D., Limbach, P.A., Clarke, S.G., and Downiea, A.B. (2013).An Arabidopsis ATPdependent, DEAD-box RNA helicase loses activity upon isoAsp formation but is restored by Protein Isoaspartyl Methyltransferase. The Plant Cell 25, 2573-2586

Nevo, E., Fu, Y.B., Pavlicek, T., Khalifa, S., Tavasi, M., and Beiles, A. (2012). Evolution of wild cereals during 28 years of global warming in Israel. PNAS USA 109,3412-3415.

Nguyen, T.P., Keizer, P., van Eeuwijk, F.A., Smeekens, S., and Bentsink, L. (2012). Natural variation for seed longevity and seed dormancy are negatively correlated in Arabidopsis. Plant Physoil.160, 2083-2092.

Nonogaki, H., Bassel, G.W., and Bewley, J.D. (2010).Germination-still a mystery. Plant Sci. 179(6), 574-581.

Oge, L., Bourdais, G., Bove, J., Collet, B., Godin, B., Granier, F., Boutin, J.P., Job, D., Jullien, M., and Grappin, P. (2008). Protein Repair L-Isoaspartyl Methyltransferase 1 is involved in both seed longevity and germination vigor in Arabidopsis. The Plant Cell 20, 3022-3037.

Osborne, D.J.(2000).Hazards of a germinating seed: available water and the maintenance of genomic integrity. Isr. J. Plant Sci. 48, 173-179.

Osborne, D.J.(1981).Sharon R, Ben-Ishai R. (1981) Studies on DNA integrity and DNA repair in germinating embryos of rye (Secale cereale). Isr. J. Bot. 29, 259-272.

Ozga, J.A., and Ayele, B.T. (2012). Developmental and seed aging mediated regulation of 
antioxidative genes and differential expression of proteins during pre- and post-germinative phases in pea.J. Plant Physiol. 169, 1477- 1488.

Padaria, J.C., Vishwakarma, H., Biswas, K., Jasrotia, R.S., Singh, G.P. (2014),Molecular cloning and in-silico characterization of high temperature stress responsive pAPX gene isolated from heat tolerant Indian wheat cv. Raj 3765. BMC Res. Notes 7, 713.

Park, W., Li, J., Song, R., Messing, J., and Chen, X.M. (2002). CARPEL FACTORY, a Dicer homolog, and HEN1, a novel protein, act in microRNA metabolism in Arabidopsis thaliana. Current Biology12, 1484-1495.

Parmenter, N.W., Berjak, P. (1999). A review of recalcitrant seed physiology in relation to dessication-tolerance mechanisms, Seed Sci. Res. 9, 13-37.

Passardi, F., Penel, C., Dunand, C.(2004). Performing the paradoxical: how plant peroxidases modify the cell wall. Trends Plant Sci. 9, 534-40.

Portis, E., Acquadro, A., Comino, C., and Lanteri, S. (2004). Analysis of DNA methylation during germination of pepper (Capsicum annuum L.) seeds using methylation-sensitive amplification polymorphism (MSAP). Plant Sci. 166, 169-178

Priestley, D.A., Cullinan, V.I., Wolfe, J. (1985). Differences in seed longevity at the species level. Plant Cell Environ. 8, 557-562.

Priestley, D.A. (1986). Seed aging. Implications of seed storage and persistence in the soil. Ithaca, NY, Cornell University Press.

Rajjou, L., Duval, M., Gallardo, K., Catusse, J., Bally, J., Job, C., and Job, D. (2012). Seed Germination and Vigor. Ann. Rev. Plant Biol. 63,507-33.

Rajjou, L., Lovigny, Y., Groot, S.P.C., Belghazi, M., Job, C., Job, D.(2008). Proteome-wide characterization of seed aging in Arabidopsis: a comparison between artificial and natural aging protocols. Plant Physiol. I148, 620-41.

Reape, T.J., and McCabe,P.F.(2008). Apoptotic-like programmed cell death in plants Rev. Bras. Sem. 30, 175-180.

Reyes, J.L., and Chua,N.H. (2007). ABA induction of miR159 controls transcript levels of two MYB factors during Arabidopsis seed germination. The Plant Journal 49, 592-606.

Riha, K., Fajkus, J., Siroky, S., Vyskot, B. (1998). Developmental control of telomere lengths and telomerase activity in plants. The Plant Cell 10, 1691-1698.

Riha, K., Watson, J.M., Parkey, J., Shippen, D.E. (2002). Telomere length deregulation and enhanced sensitivity to genotoxic stress in Arabidopsis mutants deficient in Ku70. EMBO Journal 21, 2819-2826.

Roberts, E.H.,(1973). Predicting the storage life of seeds. Seed Sci. Technol. 1, 499-514

Rodriguez, A.A., Grunberg, K.A., Taleinsnik, G.F. (2002). Reactive oxygen species in the elongation zone of maize leaves are necessary for leaf extension. Plant Physiol. 1129, 1627-32.

Rogers, K., and Chen, X.M. (2013). Biogenesis, turnover, and mode of action of plant microRNAs. The Plant Cell 25, 2383-2399.

Santhy, V., Meshram, M., Wakde, R., and Vijaja Kumari, P.R. (2014). Hydrogen Peroxide pre treatment for seed enhancement in cotton(Gossypium hirstum L.). Afr. J. Agric. Res. 9, 1982-1989.

Scheler, C., Weitbrecht, K., Pearce, S.P., Hampstead, A., Buttner-Mainik, A., Lee, K.J., et al. (2015). Promotion of testa rupture during garden cress germination involves seed compartmentspecific expression and activity of methylesterases. Plant Physiol. 167, 200-215.

Schoen, D.J., David, J.L., Bataillon, T.M. (1998). Deleterious mutation and the regeneration of plant genetic resources. PNAS 95,394-399.

Schopfer, P., Plachy, C., Frahry, G. (2001).Release of reactive oxygen intermediates (superoxide radicals, hydrogen peroxide, hydroxyl radicals) and peroxidase in germinating radish (Raphanus sativus L.) seeds controlled by light, gibberellin and abscisic acid. Plant Physiol, 125, 1591-602.

Shah, Z.H., Hamooh, B.T., Daur, I., Rehman, H.M., Alghabari, F. (2017). Transcriptomics and Biochemical profiling: current dynamics in elucidating the potential attributes of olive. Curr. Issues Mol. Biol. 21, 73-98.

Shatters, R.G., Schweder, M.E., West, S.H., Abdelghany, A., Smith, R.L. (1995). Environmentally-induced polymorphisms detected by RAPD analysis of soybean seed DNA. Seed Sci. Res. 5, 109-116.

Shelar, V.R., Shaikh, R.S., Nikam, A.S. (2008). Soybean seed quality during storage: A review, Agric. Rev. 29(2), 125-131.

Shen-Miller, J. (2002). Sacred lotus, the long-living fruits of China Antique. Seed Sci. Res. 12,131-43

Singh, M., Singh, S., Randhawa, H., and Singh, J. (2013). Polymorphic homoeolog of key gene of RdDM pathway, ARGONAUTE4_9 class is associated with pre-harvest sprouting in wheat (Triticum aestivum L.) PLoS ONE8(10), e77009.

Slupphaug, G., Kavli, B., Krokan, H.E. (2003). The interacting pathways for prevention and repair of 
oxidative DNA damage. Mutation Research 531, 231-251.

Smith, M.T., Berjak, P. (1995). Deteriorative changes associated with the loss viability of stored desiccation tolerant and desiccationsensitive seeds. In: Kigel J, Galili G. eds. Seed development and germination. New York, NY: Marcel Dekker, 701-46.

Smith, R.D., Dickie, J.D., Linington, S.H., Pritchard, H.W., Probert, R.J. (2003). Seed conservation: turning science into practice. London: Royal Botanic Gardens, Kew.

Song, J.B.,, S., Wang, Y.,Wen, B., Yong, L., Zhang, L.,Yang, Z.M. (2016).miR394 and its target gene $\mathrm{LCR}$ are involved in cold stress response in Arabidopsis. Plant Gene 5, 56-64.

Sreenivasulu, N., and Wobus, U. (2013). Seeddevelopment programs: a systems biology-based comparison between dicots and monocots. Ann. Rev. Plant Biol. 64, 189-217.

Stein, J.C., Hansen, G. (1999). Mannose induces an endonuclease responsible for DNA laddering in plant cells. Plant Physiol. 121, 71-80.

Talai, S., Sen-Mandi, S. (2010). Seed vigour-related DNA marker in rice shows homology with acetyl CoA carboxylase gene. Acta Physiol. Plant. 32, 153-167.

Talasz, H., Wasserer, S., Puschendorf, B. (2002). Non-enzymatic glycation of histones in vitro and in vivo, J. Cell. Biochem. 85, 24-34.

Tatton, W.G., Olanow, C.W. (1999). Apoptosis in neurodegenerative diseases: the role of mitochondria. Biochimica et Biophysica Acta 1410, 195-213.

Tekrony, D.M.,And EGLI DB (1991). Relationship of seed vigour to crop yield: A review. Crop Sci. 31, 816-822.

Theresa, J., Reape, and Paul,McCabe, F. (2008) Apoptotic-like programmed cell death in plants New Phytologist180, 13-26.

Tolleter, D., Hincho, D.K., Macherel, D. (2010). A mitochondrial late embryogenesis abundant protein stabilizes model membrane in the dry state, Biochem. Biophys. Acta, 1798, 1926-1933.

Vacca, R.A., de Pinto, M.C., Valenti, D., Passerella, S., Marra, E., De Gara, L. (2004). Production of reactive oxygen species, alteration of cytosolic ascorbate peroxidase, and impairment of mitochondrial metabolism are early events in heat shock-induced programmed cell death in tobacco Bright-Yellow 2 cells. Plant Physiol. 134, 1100-1112.

Vacca, R.A., Valenti, D., Bobba, A., Merafina, R.S., Passarella, S., and Marra, E. (2006). Cytochrome $C$ is released in a reactive oxygen species- dependent manner and is degraded via Caspaselike proteases in tobacco Bright-Yellow 2 cells en route to heat shock-induced cell death. Plant Physiol. 141, 208-219

Ventura, L., Donà, M., Macovei, A.,Carbonera, D., Buttafava, A., Mondoni, A., Rossi, G., and Balestrazzi,A. (2012). Understanding the molecular pathways associated with seed vigor. Plant Physiol. Biochem. 60,196-206

Verma, S.S., Tomer, R.P.S., Verma, U. (2003). Loss of viability and vigor in Indian mustard seeds stored under Ambient conditions. Seed Res. 31(1), 98-101.

Verma, P., Kaur, H., Petla, B.P., Rao, V., Saxena, S.C., and Majee, M. (2013). Protein LIsoaspartylMethyltransferase 2 gene is differentially expressed in chickpea and enhances seed vigor and longevity by reducing abnormal isoaspartyl accumulation predominantly in seed nuclear proteins.Plant Physiol. 161(3), 1141-57.

Vijay, D., Dadlani, M., Kumar, P.A., Panguluri, S.K. (2009). Molecular marker analysis of differentially aged seeds of soybean and safflower. Plant Mol. Biol. Report. 27, 282-291.

Wagner, M.H., Ducournau, S., Luciani, A., and Léchappé, J. (2012). From knowledge-based research towards accurate and rapid testing of seed quality in winter rape. Seed Sci. Res. 22, 80-85.

Walters, C., Wheeler, L.M., Grotenhuis, J.M. (2005). Longevity of seeds stored in a genebank: species characteristics. Seed Sci. Res. 15, 1-20.

Walters C. 1998. Understanding the mechanisms and kinetics of seed ageing. Seed Sci. Res. 8, 223-244.

Walters, C., Ballesteros, D., Vertucci, V. A. (2010).Structural mechanics of seed deterioration: Standing the test of time, Plant Sci. 179, 565-573.

Wang, W.Q., Cheng, H.Y., Møller, I.M., and Song, S.Q. (2012). The role of recovery of mitochondrial structure and function in desiccation tolerance of pea seeds. Physiol. Plant.144(1), 20-34

Wang, Z., Khee, D.B., Lu, J., Bohr, C.T., Zhou, F., Vallabhaneni, H., de Souza-Pinto, N.C., Liu, Y. (2010). Characterization of oxidative guanine damage and repair in mammalian telomeres. PLoS Genetics 6, e1000951.

Wang, Z., Khee, D.B., Lu, J., Bohr, C.T., Zhou, F., Vallabhaneni, H., de Souza-Pinto, N.C., Liu, Y. (2010). Characterization of oxidative guanine damage and repair in mammalian telomeres. PLoS Genetics 6, e1000951.

Waterworth, W.M., Masnavi, G., Bhardwaj, R.M., Jiang, Q., Bray, C.M., and West, C.E. (2010). A 
plant DNA ligase is an important determinant of seed longevity. The Plant Journal, 63, 848-860.

Watson, J.M., and Riha, K. (2011).Telomeres, aging, and plants: from weeds to Methuselah. A MiniReview Gerontology, 57, 129-136.

Weber, H., Borisjuk, L., and Wobus, U. (2005). Molecular physiology of legume seed development. Ann. Rev. Plant Biol. 56, 253-279.

Wei, Y.H., Lee, H.C. (2002). Oxidative stress, mitochondrial DNA mutation, and impairment of antioxidant enzymes in aging. Exp. Biol. Med. 227, 671-682.

Weitbrecht, K., Müller, K., and Leubner-Metzger, G. (2011). First off the mark: early seed germination. J. Exp. Bot. 62 (10), 289-3309.

Weitbrecht, K., Mulle,r K., Leubner-Metzger, G. (2011). First off the mark: early seed germination, J. Exp. Bot. 62, 3289-3309.

Wituszynska, W., Szechynska-Hebda, M., Rusaczonek, A., Kowzlowska, A. (2015). Leision simulating disease 1 and enhanced disease susceptibility 1 differentially regulate UV-C induced photooxidative stress signalling and programmed cell death in Arabidopsis thaliana. Plant Cell Environ. 38, 315530.
Wojtyla, L., Garnczarska, M., Zalewski, T., Bednarski, W., Ratajezak, L., Jurga, S. (2006). A comparative study of water distribution, free radical production and activation of antioxidative metabolism in germinating pea seeds. J. Plant Physiol 163, 1207-1220.

Yang, Y., Zhong, J., Ouyang, Y., and Yao, J. (2013). The integrative expression and co-expression analysis of the AGO gene family in rice. Gene 528, 221-235.

Yao, Z., Liu, L., Gao, F., Rampitsch, C., Reinecke, D.M., Ozga, J.A., and Ayele,B.T. (2012). Developmentaland seed aging mediated regulation of antioxidative genes and differential expression of proteins during pre- and postgerminative phases in pea. J. Plant Physiol. 169, 1477- 1488.

Yu, X., Pasternak, T., Eiblmeier, M., Ditengou, F., Kochersperger, P., Sun, J., Wang, H., Rennenberg, H., Teale, W., Paponov, I., Zhou, W., Li, C., Li, X., Palme, K. (2013). Plastidlocalized glutathione reductase2-regulated glutathione redox status is essential for Arabidopsis root apical meristem maintenance. Plant Cell 25(11), 4451-61. 
